Quicksilver

Deposits

\title{
of Chile
}

GEOLOGICAL SURVEY BULLETIN 964-E

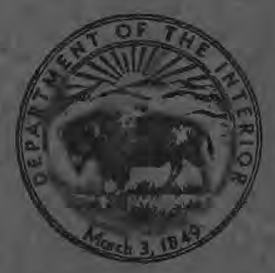




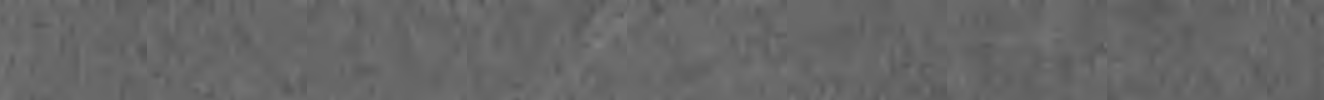

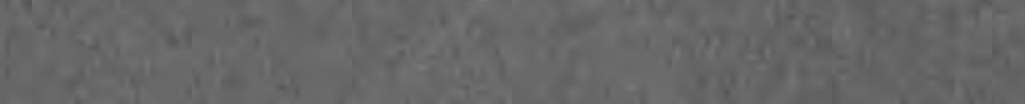

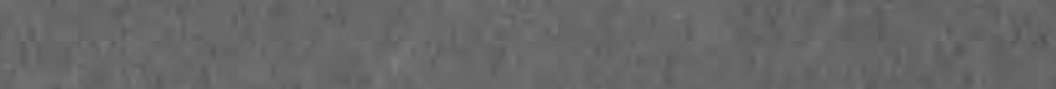

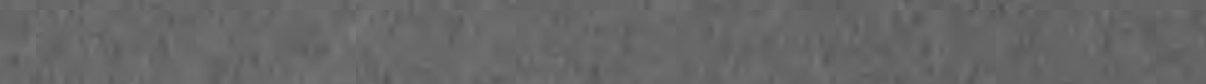

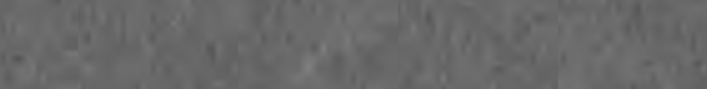

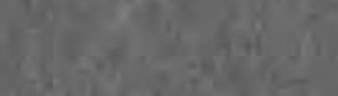

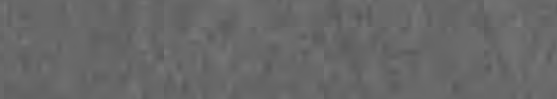

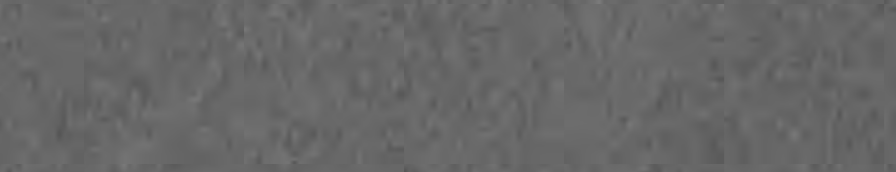

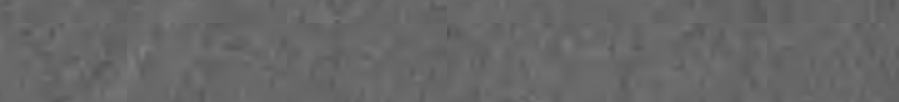

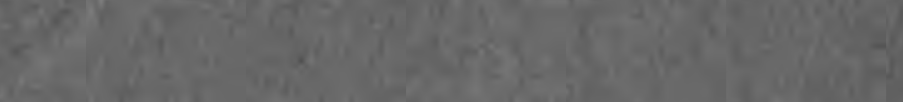

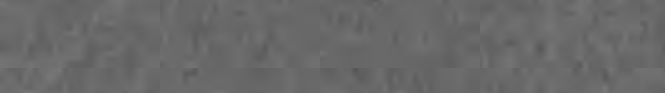

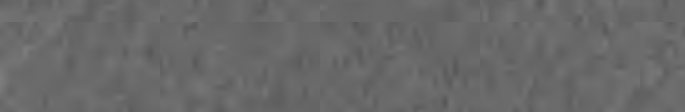

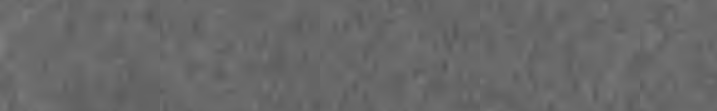

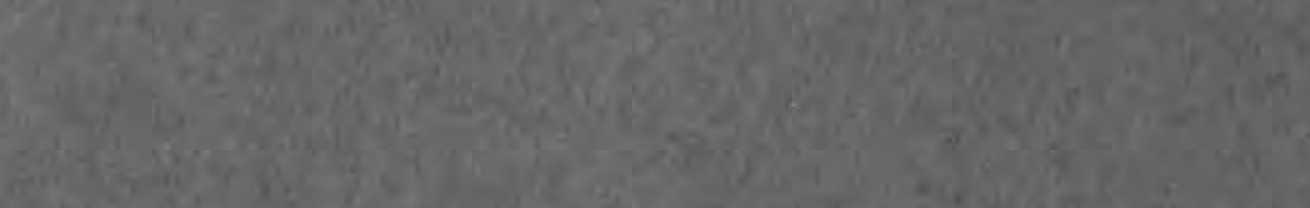
ing

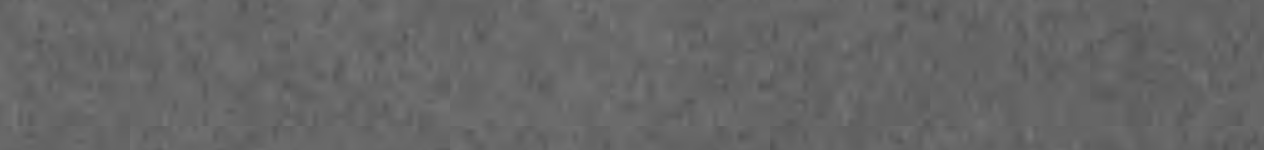

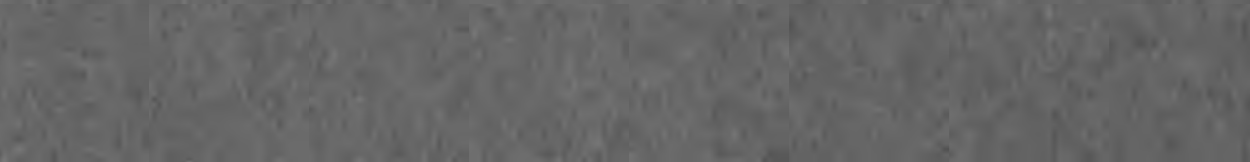
ind,

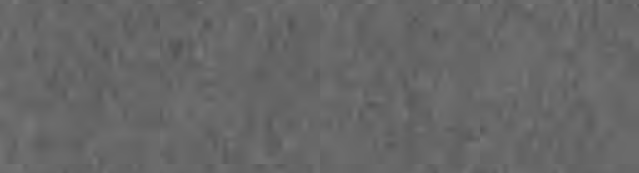

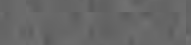

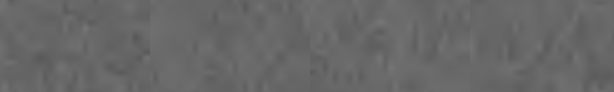

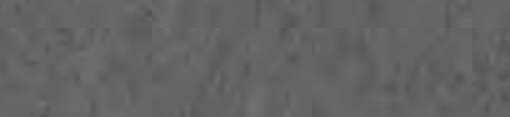
M. $\frac{12}{4}$

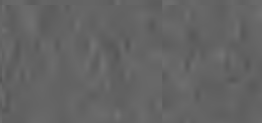
Sol 


\section{Quicksilver}

Deposits

of Chile

By J. F. McALLISTER, HECTOR FLORES W., and CARLOS RUIZ F.

GEOLOGIC INVESTIGATIONS IN THE AMERICAN REPUBLICS, 1949

G E O L O G I A L S U R VEY B U L L E T I N 964-E

Published in cooperation with the Departamento de Minas y Petróleo, Chile, under the auspices of the Interdepartmental Committee on Scientific and Cultural Cooperation, Department of State

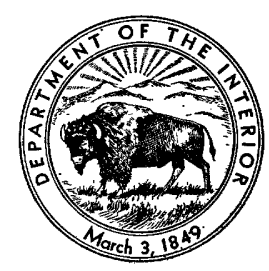




\section{UNITED STATES DEPARTMENT OF THE INTERIOR}

Oscar L. Chapman, Secretary

\section{GEOLOGIGAL SURVEY}

W. E. Wrather, Director 


\section{CONTENTS}

Abstract

Introduction

Regional geology of the quicksilver zone.

Ore deposits

Mineralogy _...

Mercury minerals

Native mercury

Cinnabar....-.

Mercurian tetrahedrite

Associated minerals

Azurite and malachite.........

Barite..... . . .

Calcite....

Chalcocite.

Chalcopyrite

Hematite

Limonite.

Magnetite

Manganese oxides . .

Pyrite

Quartz

History of the minerals . . 370

Distribution . . 372

Size and grade

Reserves...

Quicksilver districts_._. 373

Punitaqui _.

Rocks_...

Structure

Minerals_...

Los Mantos mine

Champurria mine

Azogues mine

Culebra adit .......... 382

Delirio-Republicana mine..... 384

Huanillo

Algarrobo mine

Illapel_..... 387

Azogues mine

Andacollo . . . 387

Dichosa mine . .

Merceditas mine _. . . . 38

Domeyko _..

Luisiana mine ... 
Quicksilver districts-Continued Page

Copiap6 . . . 391

Cerro Blanco

Mirador property

Cerro del Fraile .

Tres Hermanos mine

Negra mine

Candelaria mine

Sierra la Plata ............. 394

Regalona prospect.

Alianza mine......... 394

Metric equivalents_._. 398

Index

\section{ILLUSTRATIONS}

Plate 20. Geologic and topographic map of the Punitaqui quicksilver district, Coquimbo, Chile.

Page In pocket

21. Geologic map of the $\mathbf{1 7 0}$ level, Los Mantos mine, Punitaqui, Chile

22. Geologic map of the 250 level, Los Mantos mine, Punitaqui, Chile

23. Geologic sections, Los Mantos mine, Punitaqui, Chile _..... In pocket

24. Geologic map of the 330 adit, Los Mantos mine, Punitaqui, Chile

25. Geologic maps of exploration adits, Los Mantos mine, Punitaqui, Chile...... In pocket

26. Geologic map of the 370 level, Champurria mine, Punitaqui, Chile . . . . . . . In pocket

27. Geologic maps and sections of the Delirio-Republicana mine, Punitaqui, Chile.... In pocket

28. Geologic sketch map of the Dichosa quicksilver mine, Andacollo, Chile . . . . . .

29. Geologic and topographic sketch map, Merceditas quicksilver deposit, Andacollo, Chile......................... In pocket

30. Geologic map of the Mirador quicksilver deposit, Cerro Blanco, Copiap6, Chile._.... In pocket

FIgURE 39. Index map of Chile, showing quicksilver region

40. Geologic map of the main level, Azogues mine, Punitaqui,

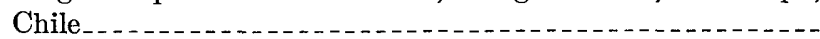

41. Geologic map of the Culebra adit, Punitaqui, Chile

42. Geologic map and section of the Luisiana quicksilver mine,

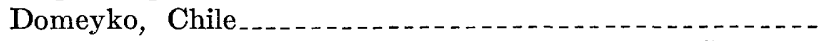

43. Geologic map of the Alianza quicksilver deposit, Sierra la

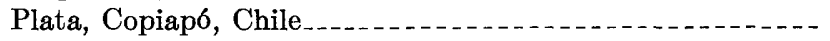

44. Plan and projection of the Alianza mine, Sierra la Plata, Copiapo, Chile. 


\title{
QUICKSILVER DEPOSITS OF GHILE
}

\author{
By J. F. Mcallister, Héctor Flores W., and Carlos Ruiz F.
}

\section{ABSTRACT}

Quicksilver has been mined intermittently in Chile since the end of the 18th century, but only in small quantities for local use until recently, when the large mine at Punitaqui started producing an average of 2,000 flasks annually for export.

The deposits, most of which are small, are in a narrow strip about 500 kilometers long, extending from Copiapó to Illapel, in north-central Chile. They are with few exceptions in the Porfiritica formation, consisting of Mesozoic andesitic rocks, and are generally near intrusive bodies of granodiorite, which is a facies of the Andean diorite complex. Most of the ore was localized in shattered and crushed zones along steep faults, some of which were formed by strike-slip shearing.

The principal ore minerals are coarse-grained cinnabar, mercurian tetrahedrite, and powdery cinnabar mixed with oxides of iron and antimony in the weathered veins. The mercurian tetrahedrite and powdery cinnabar are the most characteristic minerals of the deposits. A little native mercury occurs in places. The coarse-grained cinnabar and mercurian tetrahedrite are hypogene minerals, and the powdery cinnabar mixture, which is closely associated with copper carbonates and limonite, is of supergene origin, having been formed by the weathering of the mercurian tetrahedrite. Vein minerals associated with the mercury minerals are, roughly in the order of deposition: calcite, specular hematite, magnetite, barite, quartz, pyrite, chalcopyrite, chalcocite, and products of weathering such as azurite, malachite, and limonite. Some of the pyrite encloses gold.

Reserves had been measured at only one mine, wher'e exploitation of mercury depended on profitable extraction of gold and copper. Reserves even of inferred ore at other places in Chile are small and economically marginal. The quicksilver districts are described in detail.

\section{INTRODUCTION}

The quicksilver deposits of Chile, with few known exceptions, lie within a narrow strip extending for about 500 kilometers; at the north end is Copiapó, and at the south end is Illapel, about 200 kilometers airline north of Santiago. Most of the deposits lie nearer to the ends of the strip than to the middle. (See fig. 39.) The northern 100 kilometers contains the Alianza mine and Regalona prospect in the La Plata district, the Tres Hermanos, Negra, and Candelaria properties in the Cerro del Fraile, and the Mirador property near Cerro Blanco. 


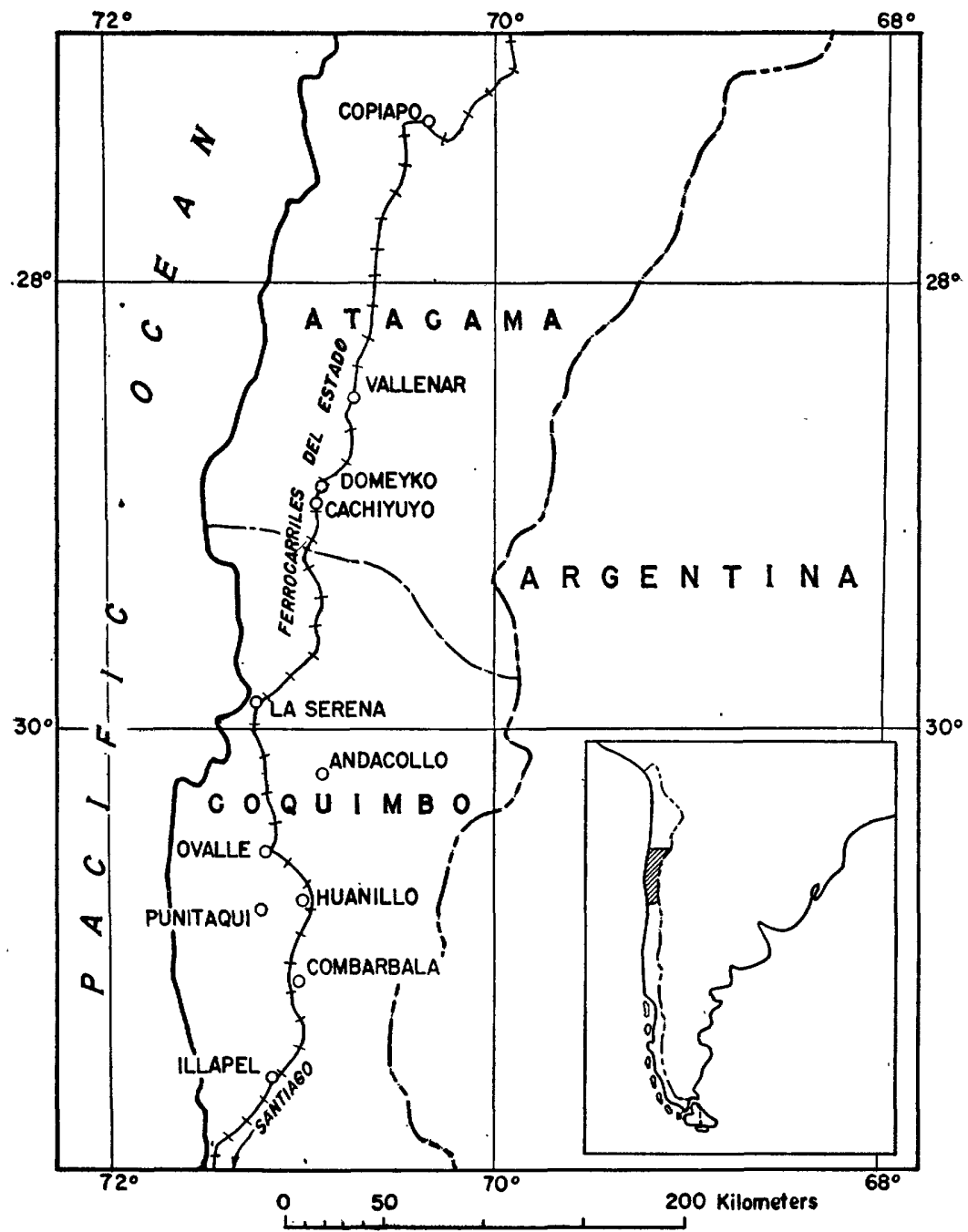

Figdre 39.-Index map of Chile, showing quicksilver region.

In the southern 150 kilometers the following properties were examined: in the Punitaqui area, the Los Mantos, the Delirio-Republicana, and the Azogues mines, part of the Champurria mine, and part of the Santa Inés property, including the Culebra adit; near Huanillo, the Algarrobo mine; and south of Andacollo, the Dichosa and Merceditas mines. A property north of Combarbalá, and the Azogues mine north of Illapel, were not examined. The region between the northern and southern groups seems barren except for the Luisiana mine, west of Cachiyuyo.

The deposits are at moderately low altitudes as they lie in the zone where the foothills of the Andes merge with the Coast Range. They 
are within 50 kilometers of the longitudinal highway and railroad, but the side roads to some of them are indirect. The sparse vegetation does not include trees suitable for mine timbers, and would not yield sufficient fuel for even moderately large operations. The climate is no hindrance to mining at any time of the year. Rock exposures at most places are good.

No complete history of mercury mining in Chile has been compiled, but fragments of the story in mining publications indicate that some of the deposits have been worked intermittently since the Spanish colonial period. The first discovery was made near Andacollo in $1778^{1}$, and the next at Punitaqui in 1785. ${ }^{2}$ The deposits were mined at first by the Spanish Government. The small quantity of mercury recovered was used at the local gold and silver mines, whenever it could compete successfully with the high-priced Peruvian and Spanish metal.

Mining seems to have been interrupted by long periods of inactivity, and there are few records of the meager production. The Punitaqui mine, which contains the largest deposit, probably was abandoned during the second decade of the nineteenth century but was reopened about 50 years later $;^{3}$ in 1874 it yielded about 800 flasks of mercury. ${ }^{4}$ A bout 60 flasks were shipped by railroad from the Andacollo district in 1918-19, according to Sr. Tomás Whittle, ${ }^{5}$ and during the next two decades only enough was produced to supply the needs of the Andacollo gold miners. The great rise in mercury prices caused by World War II revived interest in mercury mining to such an extent that Chile in 1941 exported about 1,300 flasks, in 1942 about, 2,300 flasks, and in 1943 at least 2,500 flasks; it exported considerably less in 1944. According to the best information and estimates available, Chile in 1943 held seventh position among non-Axis producers, following Spain, the United States, Mexico, Canada, Russia, and China, and contributed about 1.4 percent of the non-Axis production.

The work upon which this report is based was carried on by the U. S. Geological Survey, Department of the Interior, in cooperation with the Chilean Departamento de Minas y Petróleo, as part of a cooperative program sponsored by the Interdepartmental Committee on Scientific and Cultural Cooperation, under the auspices of the United States Department of State.

Field work was carried on between February and August, 1944. Flores, of the Departamento de Minas y Petróleo, and McAllister,

\footnotetext{
${ }^{1}$ Whittle, Tomás, Explotación de las minas de mercurio : Bol. minero, vol. 44, p. 3, Sant1ago, Chile, 1932.

${ }^{2}$ Kuntz, Julio, Monografía minera de la Provincia de Coquimbo : Bol. minero, vol. 37, p. 865, Santiago, Chile, 1925.

Kuntz, Julio, op. cit., p. 865.

Whittle, Tomás, op, cit., p. 4.

- Whittle, Tomás, oral communication, 1944.
} 
of the Geological Survey, collaborated in mapping part of the areal and mine geology in the Punitaqui district until Flores was obliged to resume his duties as professor at the Universidad de Chile. In June, McAllister was joined by Ruiz, of the Departamento de Minas $y$ Petróleo, who collaborated in the remaining field work.

Base maps of some mines (pls. 21, 22, 24, 25, 26, 27; figs. 40, 41, 44) and one topographic map (part of pl. 20) were furnished by property owners, as acknowledged on the illustrations. The writers surveyed other mines with Brunton and tape, and mapped the areal geology and topography with plane table. They are responsible for all geologic information on the maps.

The writers are greatly indebted to officials of the Compañía Minera Punitaqui, S. A., especially to Sr. José Luis Claro, Sr. Ricardo Fritis, Sr. Moisés Silbermann, Sr. José Ayala, and Sr. Horacio Gallo, for their generous cooperation in furnishing information and maps, for their hospitality, and for many other courtesies. They are similarly indebted to Sr. Sali Hochschild, president of the Compañía Minera Delirio de Punitaqui, and to Mr. O. M. Brown, consulting engineer of the company. It is also a pleasure to acknowledge the cooperation and help in various ways of Sr. Tomás Whittle of Andacollo; of the Toro brothers of Cerro del Fraile, Copiapó; officers of the Compañía Minera Monte Patria ; of officials of the Caja de Crédito Minero, especially Sr. Fernando Benítez and Sr. Luis Kaiser; and of others in Chilean Government agencies, whose attentions, although too varied to enumerate, are sincerely appreciated.

\section{- REGIONAL GEOLOGY OF THE QUICKSILVER ZONE}

The oldest rocks of north-central Chile consist of pre-Cambrian regionally metamorphosed rocks, chiefly amphibolite and mica schist, and of Paleozoic shale, sandstone, and conglomerate. All these rocks occur in small strips along the coast. ${ }^{6}$

Of far greater extent are Mesozoic volcanic rocks and interbedded limestones. This assemblage, where not subdivided and especially where limestones are thin or lacking, is known as the "Formación Porfiritica"-literally the "porphyrite formation." 7 This unit includes porphyritic andesite, andesitic tuff and breccia, and conglomerate derived from them. The formation is more than a thousand meters thick, according to Brüggen, ${ }^{8}$ who described the igneous rocks

\footnotetext{
${ }^{6}$ Muñoz Cristi, Jorge, Rasgos generales de la constitución geologica de la Cordillera de la Costa, especialmente en la Provincia de Coquimbo: Anales Primer Congreso Panamericano de Ingeniería de Minas y Geología, vol. 2, pp. 290-300, Santiago, Chile, 1942. Reseña de la geología de Chile, p. 7, Centro de estudiantes de ingeniería de minas, Univ. Chile, 1947.

${ }^{7}$ In Chile it is acceptable to use a rock name in place of a geographic name with the term "formation," and it is customary there to call a Mesozoic andesite a porphyrite; to avoid confusion, therefore, the Chilean term "Formacion Porfiritica" will be retained, but anglicized as "Porfiritica formation."

${ }^{8}$ Brüggen, Johannes, Grundzüge der Geologie und Lagerstättenkunde Chiles : Math.Naturwiss. Klasse der Heidelberger Akad. der Wiss., 1934.
} 
as being mostly reddish, greenish, and dark-gray augite porphyrite, labradorite porphyrite, melaphyre, and diabase, and as including some quartz porphyrite and orthophyre.

In thin sections of somewhat altered porphyritic andesite of the Porfiritica formation near Andacollo, there are phenocrysts of andesine, most of which are between 1 and 2.5 millimeters long but ranging in length from 0.5 to 5 millimeters, and phenocrysts of hornblende, which tend to be much smaller, averaging about 0.5 millimeter in length. The groundmass consists chiefly of plagioclase laths, mostly about 0.1 millimeter long, showing a more or less distinct flow structure. The rock contains a little original interstitial quartz, some apatite grains up to half a millimeter in diameter, and abundant euhedral magnetite. The feldspar is cloudy, and the hornblende has been partly replaced by biotite and later altered to chlorite, calcite, and epidote.

The associated limestones are inconspicuous in the southern half of the mercury-bearing zone, but they form prominent thick layers farther north, between Vallenar and Copiapó, where they have been given formation names. ${ }^{9}$ At the base of the Porfiritica formation there are some calcareous rocks of Lower and Middle Jurassic age (Lias and Dogger), those of Middle Jurassic age predominating toward the north. Near the top there are Upper Jurassic limestones, which grade into Lower Cretaceous (Neocomian) limestones..$^{10}$

In later Cretaceous and early Tertiary time the Mesozoic and older rocks were intruded by quartz diorite and related rocks. ${ }^{11}$ Although quartz diorite has been considered the usual rock of the intrusive masses, the rocks observed in this study include some that vary from granite through diorite to gabbro, ${ }^{12}$ and biotite-hornblende granodiorite is the usual facies in the quicksilver districts that were examined. The entire suite has been called in late reports the Andean diorite. These rocks have been called also the Inclusion granite, ${ }^{13}$ because of the conspicuous inclusions, which are characteristically widespread. Andean diorite complex will be used in this report.

\footnotetext{
- Biese-Nickel, W. A., La distribución del Cretaceo Inferior al sur de Copiapo : Anales Primer Congreso Panamericano de Ingeniería de Minas y Geología, vol. 2, pp. 430-445, Santiago, Chile, 1942.

${ }^{10}$ Biese-Nickel, W. A., op. cit. Flores W., Héctor, Geología de los Yacimientos de Cobre y Oro de Chile, Anales Primer Congreso Panamericano de Igeniería de Minas y Geología vol. 3, p. 1146. Santiago, Chile, 1942. Neuenschwander, C. R., and Tavera J., Juan, Yacimiento de plomo y Neocomiano de "Las Cañas" en el Departamento de Vallenar: Anales Primer Congreso Panamericano de Ingeniería de Minas y Geología, vol. 3, pp. 1099, 1106, 1108, Santiago, Chile 1942.

11 Flores W., Hector, idem, p. 1146.

12 Kaiser, Luis, La Diorita Andina de Guangali, Provincia de Coquimbo y su aureola metamorfica : Bol, Minero, vol. 51, pp. 834-844, Santiago, Chile, 1939. Ruiz, Carlos, Estudio geologico de la región Ojancos-Punta del Cobre; idem., vol. 3, pp. 1199-1205, 1942.

${ }^{13}$ Little, J. M., The geology and metal deposits of Chile, pp. 11-12. New Xork, Branwell Co., 1926.
} 
Dikes of dark rock are closely associated with many of the vein deposits in central Chile. The rock has commonly been called lamprophyre in the literature, its original nature being in many places so difficult to ascertain that it cannot be given a more specific name. It is for the most part thoroughly altered, largely to chlorite, but it seems to have consisted originally of a coarse felty aggregate of plagioclase and mafic minerals, the latter perhaps predominating. In some places there are phenocrysts of plagioclase and the mafic minerals; the latter show the outline of pyroxene in thin sections from some specimens, but clusters of hornblende needles are visible to the unaided eye in other specimens. Euhedral magnetite is conspicuously abundant. The feldspar of the least altered rock examined is andesine, but in altered rock it is albite. These rocks will be referred to in this report as lamprophyres. 'The dikes are mostly from 1 to 2 meters wide, although in some places they bulge abruptly to form thick masses. Their walls are sharply defined. Apophyses a few centimeters to several meters long, with fine-grained borders indicating chilling, follow joints in granodiorite, especially at Punitaqui.

Tertiary rhyolite flows cap some of the peaks in this part of the Andes. Tertiary marine deposits are exposed along the coast, and Quaternary continental deposits occur in many large basins and along extensive river terraces.

The regional distribution of rocks in strips roughly parallel to the coast is due at least in part to the trend of major topographic relief and to the progressively greater erosional stripping nearer the coast, but it is partly due to regional eastward dips and to north-trending longitudinal faults. According to some geologists only normal faults are important in central Chile, but farther north, as in the Copiapó region, reverse and thrust faults, and possibly strike-slip faults, are noteworthy. Strike-slip zones of shearing, probably of small displacement, controlled the ore at' some of the quicksilver mines. A major structure throughout the region is the roof of a batholith that has been irregularly exposed.

\section{ORE DEPOSITS}

\section{MINERALOGY}

\section{MERCURY MINERALS}

The mercury minerals observed in the Chilean quicksilver deposits are native mercury, cinnabar, and mercurian ${ }^{14}$ tetrahedrite.

\footnotetext{
14 Use of the suffix "an," combined with the name of an element, for designating a variety of a mineral species containing that element as a minor constituent, was proposed by W. T. Schaller in Adjectival endings of chemical elements used as modifiers to mineral names : Am. Mineralogist, vol. 15, pp. 566-574, 1930, and was adopted for the latest edition of Dana's System of mineralogy (1944). Schwatzite thus becomes a synonym of mercurian tetrahedrite.
} 
Native mercury $(\boldsymbol{H} g)$.-Although native mercury has been reported from several mines, it was seen only in one large specimen from the Los Mantos mine at Punitaqui. It formed globules, associated with massive limonite, in small cavities in a porous aggregate of quartz which also contained coarsely crystalline cinnabar.

Cinnabar $(H g S)$. - Two kinds of cinnabar are common in the Chilean deposits--a coarsely crystalline, pure cinnabar and a finegrained earthy mixture. The coarsely crystalline variety forms highly lustrous deep-red grains, which grew interstitially or replaced the gangue. It occurs in both unoxidized and oxidized veins, and makes the best ore. The powdery cinnabar grades from light vermilion to brick red, is earthy, and is mixed with oxides of iron, antimony, and probably copper. It is found only in oxidized material, and almost all of it is associated with limonite and carbonates of copper. It has long been known popularly as "yuyo," and more formally as ammiolite. Ignacio Domeyko ${ }^{15}$ had some analyzed in the middle of the last century, and reported in 1900 that the purest powder he could separate contained the following:

\begin{tabular}{|c|c|c|}
\hline & rcent & Percent \\
\hline Antimonic acid_... & 24.1 & 23.1 \\
\hline Mercury ----------- & 19.9 & 19.8 \\
\hline Sulfur (calculated) & 3. 3 & 3.1 \\
\hline Copper oxide... & 16.9 & 18. 1 \\
\hline Iron oxide & 2.2 & 1.1 \\
\hline Siliceous gangue & 24.8 & ---- \\
\hline Water - & 8.8 & --- \\
\hline
\end{tabular}

An approximate partial analysis by Ledoux and Co. of a sample too small for an accurate determination-only 300 milligrams-gave the following:

\begin{tabular}{|c|c|c|}
\hline \\
\hline \multicolumn{3}{|c|}{$\begin{array}{c}\text { Percent } \\
\text { Mercury }\end{array}$} \\
\hline $\begin{array}{l}\text { Iron_-- } \\
\text { Antimon }\end{array}$ & - & $-\quad 7.0$ \\
\hline $\begin{array}{l}\text { Antimon } \\
\text { Copper }\end{array}$ & y (possibly) - & 2.0 \\
\hline $\begin{array}{l}\text { Copper } \\
\text { Sulfur-- }\end{array}$ & (possibly ) - & $\begin{array}{l}2.0 \\
8.0\end{array}$ \\
\hline
\end{tabular}

The sulfur is present nearly in the right proportion to combine with the mercury to form cinnabar. The analyses show, at least, that the substance is a mixture containing the same elements as mercurian tetrahedrite, although in very different proportions.

Mercurian tetrahedrite $\left(5 \mathrm{C} u_{2} S .2(C u, F e, H g) S .2 S b_{2} S_{3}\right)$. -The mercurian tetrahedrite is dark gray and soft ( 3 to 4$)$ and has a metallic luster; it usually forms anhedral grains, but here and there it exhibits

${ }^{16}$ Domeyko, Ignacio, Mineralojía, vol. 4, pp. 458-459, Santiago, Chile, 1900. 
the section typical of tetrahedrite. Almost all the tetrahedrite examined in polished sections encloses minute grains of chalcopyrite, and in a few places it contains distinct veinlets of chalcopyrite. Some analyses reported by Domeyko ${ }^{16}$ gave the following percentages:

Analyses of mercurian tetrahedrite

\begin{tabular}{|c|c|c|c|c|}
\hline Constituent & 1 & 2 & 3 & 4 \\
\hline Antimony & 20.7 & 20.4 & 34.90 & 12.83 \\
\hline Arsenic....... & & 4. 0 & & \\
\hline $\begin{array}{l}\text { Iron } \\
\text { Zinc }\end{array}$ & $\begin{array}{l}1.5 \\
\text { tr. }\end{array}$ & 1. 3 & 0.17 & $\begin{array}{l}\text { 1. } 19 \\
\text { tr. }\end{array}$ \\
\hline Copper & 33.6 & 39.0 & $32.2 \overline{2}$ & 52.89 \\
\hline Mercury & 24.0 & 11.0 & 3. 80 & 3. 83 \\
\hline Sulfur_. & 20.2 & 24.3 & 27.85 & 18. 33 \\
\hline Gangue.... & ..... & $\ldots \ldots \ldots$ & $\ldots \ldots \ldots$ & 9.80 \\
\hline
\end{tabular}

1. Manto de Valdivia, Punitaqui. Analysis by Domeyko.

2. Lajarilla, Andacollo district. Analysis by Domeyko.

3. Fortuna mine, Talca. Analysis by Castillo.

4. Huasco, south of Vallenar.

Some mercurian tetrahedrite was noticed with the coarsely crystalline cinnabar in the lower levels of the Los Mantos mine, but ordinarily the two minerals occur separately. In weathering, the mercurian tetrahedrite breaks down to form the red earthy mixture described under cinnabar, accompanied by secondary copper minerals such as malachite and azurite. In unweathered deposits, mercurian tetrahedrite is so prominent and widespread that it is regarded by some writers as being the only original mercury mineral in the Chilean deposits, all the cinnabar presumably having been derived from it.. ${ }^{17}$ It has been suggested that even the coarse-gcained cinnabar is of supergene origin, and that it was formed by weathering of the tetrahedrite and deposited in the zone of enrichment.

\section{ASSOCIATED MINERALS}

The minerals that were observed in association with the mercurybearing minerals are described in alphabetical order.

Azurite $\left(2 \mathrm{CuCO}_{3} \cdot \mathrm{Cu}(\mathrm{OH})_{2}\right)$ and malachite $\left(\mathrm{CuCO}_{3} \cdot \mathrm{Cu}(\mathrm{OH})_{2}\right)$.Blue azurite and green malachite, probably accompanied by other copper minerals commonly found with them but not identified for this report, are characteristic of the oxidized parts of the Chilean quicksilver deposits. Much of the azurite is visibly crystalline, but much of the malachite occuring in minute cavities is very fine grained and some is typically colloform. These minerals in most places are associated with the red powdery mixture containing cinnabar which is contemporaneous with them, for it is intimately mixed with the copper car-

${ }^{16}$ Domeyko, Ignacio, Mineralojía, vol. 2, pp. 237-239, Santiago, Chile, 1897.

${ }^{17}$ Little, J. M., The geology and metal deposits of Chile, p. 77, 1926. 
bonates; the cinnabar is covered by the carbonates in some places, and coats them in others.

Barite $\left(\mathrm{BaSO}_{4}\right)$. - In the gangue of some small, widely separated - deposits, as the Algarrobo, Alianza, and Merceditas mines, moderately coarse grained barite, commonly in euhedral or subhedral plates, is second in abundance to quartz. The obviously heavy weight and platy habit of the barite easily distinguish it from the white carbonates. The barite, as can be seen in thin sections, is earlier than at least some of the quartz and earlier than all of the fine-grained cinnabar in the quartz.

Calcite $\left(\mathrm{CaCO}_{3}\right)$ - - Although calcite is relatively scarce or absent in most of the quicksilver deposits, it forms large, coarse-grained masses of anhedral grains in the Los Mantos mine, where it was the first vein mineral deposited. Many of the grains are more than 5 centimeters in diameter. The abundance of calcite at this place may be due to the closeness of the vein to limestone lenses in the Porfiritica formation. This coarse-grained early calcite tends to be moderately dark, in contrast to a late white or pink calcite, which filled some of the latest fissures.

Chalcocite $\left(\mathrm{Cu}_{2} \mathrm{~S}\right)$.- - In the Delirio mine at Punitaqui massive chalcocite was seen to enclose irregular grains of pyrite. The adjacent quartz gangue contained cinnabar and a network of malachite stringers.

Chalcopyrite $\left(\mathrm{CuFe} \mathrm{S}_{2}\right)$. - The usual hypogene copper mineral is chalcopyrite. Polished sections reveal small grains, and rarely veinlets, of chalcopyrite in nearly all the mercurian tetrahedrite examined. To a much less extent chalcopyrite is intimately associated with the coarsely crystalline cinnabar. It is probably somewhat earlier than cinnabar, later than pyrite, and nearly contemporaneous with mercurian tetrahedrite.

Hematite $\left(\mathrm{Fe}_{2} \mathrm{O}_{3}\right)$. - Specular, or micaceous hematite is moderately widespread among the quicksilver deposits and is conspicuous at Punitaqui. In coarse-grained calcite the hematite tends to follow grain boundaries and cleavage, but within the calcite grains there are individual flakes and clusters of hematite oriented in other directions. The mineral is thus later than the early coarse-grained calcite and earlier than most of the quartz, although there may have been an overlap of the specular hematite and the quartz. Resplendent flakes between 2 and 5 millimeters in diameter are not uncommon, but much of the hematite is in small flakes making up large unctuous masses.

Limonite (approximately $\mathrm{QF}_{2} \mathrm{O}_{3} \cdot \mathrm{H}_{2} \mathrm{O}$ ). - Limonite is abundant in the oxidized parts of the deposits. Some is massive and encloses specular hematite, as in the Azogues mine at Punitaqui, and in some places the earthy cinnabar mixture occupies cavities in limonite. 
Magnetite $\left(\mathrm{FeO}_{\mathrm{Fe}} \mathrm{O}_{3}\right)$.-As a vein mineral magnetite is scarce, but it occurs locally on the 388 level of the Los Mantos mine, and also in the Luisiana mine. Minute grains of it have replaced some of the specular hematite.

Manganese oxides.-Manganese oxides mixed with iron oxides are conspicuous at the Regalona prospect in the Copiapó region, where they are accompanied in several places by copper minerals of oxidation and by earthy cinnabar. The gangue is quartz and barite.

Pyrite $\left(\mathrm{FeS}_{\mathrm{e}} \mathrm{S}\right)$.-Pyrite is one of the commonest metallic minerals in the deposits. The grains tend to be euhedral, and they replace earlier minerals. Some of the pyrite in the Los Mantos mine, according to a report in the files of the Compañía Minera Punitaqui, is auriferous.

Quartz $\left(\mathrm{SiO}_{2}\right)$.-The most abundant gangue mineral is quartz. The earliest quartz replaced the country rock and, in some places, coarsely crystalline calcite. Its deposition persisted, and later quartz filled fissures and lined vugs. In general the quartz is milky white. Some of it, apparently where it did not completely replace the country rock, is somewhat grayer, has a distinctive sugary texture, and contains ill-defined patches of chloritic material.

\section{HISTORY OF THE MINERALS}

The associations of the minerals and their relationships give some indications as to the history of the deposits, but leave unanswered or speculative some fundamental questions of genesis, including some that may have a practical bearing. Some of the questions that have been considered relate to the origin of the three common mercury minerals. Were the powdery cinnabar, the coarsely crystalline cinnabar, and the mercurian tetrahedrite all deposited by hypogene solutions but under different conditions-for example at different depths or from solutions differing in composition or temperature; was the only original mercury mineral mercurian tetrahedrite, and were the two forms of cinnabar derived from it and deposited in the zone of oxidation and the zone of enrichment respectively; or were the tetrahedrite and the coarsegrained cinnabar of hypogene origin; and is the powdery cinnabar mixture an oxidation product of mercurian tetrahedrite; or were the mercury minerals deposited by the same solutions that had previously deposited copper and gold, or by distinctly later solutions that followed the same channels; or if all the metals were deposited by the same solution, at what relative temperature was the solution when each of the minerals was deposited?

The most favorable places for studying the mercury minerals and their relations to the minerals associated with them are in the Punitaqui district, especially in the Los Mantos mine. The conclusions drawn 
from the relations observed at this place were in no case contradicted by those observed at other localities, where the relations were less completely displayed. The following summary of the relations in the Punitaqui ore deposits is therefore considered representative of the Chilean mercury deposition in general.

The first vein mineral deposited was coarsely crystalline, anhedral calcite. Its distribution is restricted within narrow limits, and its origin, which therefore is somewhat problematic, is discussed in the detailed description of the deposits at Punitaqui. Coarse-grained specular hematite wes formed along cleavage planes of the calcite and between the grains, showing clearly that the hematite is later in the mineral sequence. Hematite was in turn replaced to a varying extent by magnetite, which in some places retained the outlines of the replaced hematite flakes, which are commonly contorted. Massive white quartz replaced some of the calcite, possibly while specular hematite was still forming. Later quartz, in very much smaller quantity, was deposited as one of the last hypogene minerals.

The range of pyrite in the sequence is difficult to determine. At least a part of it, associated with late veinlets of quartz and pinkish calcite, was very late. Gold was introduced with some of the pyrite.

Mercurian tetrahedrite is to some extent interstitial between the quartz grains, and in a few places euhedral grains of it have replaced quartz. It may be later than the earliest pyrite. Its close association with chalcopyrite is noteworthy, and at least a minor quantity of the chalcopyrite, forming microscopic veinlets, cuts the tetrahedrite.

Coarse-grained cinnabar is associated with the hypogene minerals, including chalcopyrite that shows no sign of enrichment by chalcocite or of weathering to copper carbonates; some of it remains, however, in zones of copper enrichment and of oxidatiton. A polished section of one specimen showed minute veinlets of cinnabar cutting chalcocite, which may indicate either that the chalcocite is of hypogene origin or that some of the cinnabar is supergene. Most, if not all, of the coarse cinnabar appears to be hypogene in origin, but if so it is distinctly late in the hypogene sequence, possibly coming last. It replaced quartz and formed between the grains of quartz, and it has a similar relation to the late pinkish calcite. The observed relations do not show conclusively whether this cinnabar, together with late quartz, pyrite, and calcite, marked the end of the main hypogene mineralization, or whether it was formed by a resurgence of the solutions along the same channels. Essentially one period of hypogene mineralization seems the more probable.

The exact place of barite in the complete series of minerals is not known, for barite was not observed at Punitaqui, but barite was deposited earlier than some of the quartz and cinnabar. 
In the weathered zone the powdery mixture containing cinnabar is closely associated with copper minerals of oxidation as well as limonite, and in places it lines cavities such as would remain after weathering of mercurian tetrahedrite. A specimen from the Andacollo district shows in thin section the fine-grained red material rimming grains of mercurian tetrahedite and cutting them as minute veinlets, precisely as limonite rims and cuts pyrite at whose expense it is being formed. These observations support the conclusion of early investigators, that the red powdery substance is an oxidation product of mercurian tetrahedrite.

In summary, answers to the questions stated above are believed to be as follows: The mercurian tetrahedrite and coarse-grained cinnabar are hypogene minerals, and the powdery cinnabar mixture is an oxidation product of mercurian tetrahedrite. The deposition of hypogene mercury minerals and of hypogene copper minerals and gold resulted from an essentially continuous process, the mercury having formed mercurian tetrahedrite at a relatively high temperature and coarsegrained cinnabar, as one of the last hypogene minerals, at a lower temperature. This interpretation implies that the coarse-grained cinnabar, at least, is not limited to a narrow depth-zone of secondary enrichment but could continue to a depth determined by the factors that controlled the entire process of mineralization. It seems improbable, however, that the mineralization extends to great depth.

\section{DISTRIBUTION}

The geographic distribution of the quicksilver ores has been outlined above and is shown in figure 39. Geologically, they are confined for the most part to rocks of the Porfiritica formation near the Andean diorite complex, but in a few places they occur within the intrusive rock, as at Algarrobo mine and north of Illapel.

Although mercury minerals were deposited in small quantity along joints leading from faults, and along flat-lying beds of tuff intersected by faults, the ore is mostly in or near the shattered and crushed rock of fault zones, and the largest deposits are in the most extensive zones of fracturing. Gouge and clay are commonly present in or near the deposits but have not exercised any obvious control on ore deposition. Further details are considered in the descriptions of individual districts.

\section{SIZE AND GRADE}

Small deposits that were sufficiently rich in mercury have been mined for mercury alone, the ore being in pockets only 2 to 15 meters long and seldom mined through a vertical distance of more than 50 meters. Where the values are chiefly in gold and copper, with quicksilver as a byproduct, as at Punitaqui, blocks as much as 100 meters 
long and mined to a depth of over 100 meters have been considered ore. At the small mines, where only the simplest types of retorts are used in recovering the mercury, only relatively high-grade ore can be mined. The production from such mines in 1944 was negligible. The only large producer, the Los Mantos mine at Punitaqui, was recovering mercury from ore that averaged about 0.1 percent mercury which was profitable only as a byproduct from gold-copper concentrates.

\section{RESERVES}

Reserves had been measured by the operators at only one mine, where exploitation depended on profitable extraction of gold. Reserves even of inferred ore at other deposits in Chile were slight and economically marginal.

\section{QUICKSIIVER DISTRICTS}

The term "district" is used loosely in this report, in order to place each of several groups of mines and deposits under the name of some well-known nearby town.

\section{PUNITAQUT}

The Punitaqui district (pl. 20), in the Provincia de Coquimbo, is easily accessible, being on the longitudinal highway, about 35 kilometers south of Ovalle, where both the main line of the railroad and the national airline have stations. It has been described in several reports..$^{18}$ The district contains the Los Mantos mine, Chile's largest gold mine and the country's only important recent producer of mercury. At the Delirio-Republicana mine, which now produces gold and copper, mercury might become a byproduct. The Azogues mine, at which mercury was the main if not the only product, is said to be the oldest quicksilver mine of the district. Other workings have produced mercury, and still contained a showing of ore when visited in 1944, but the extensive workings in Trinitaria hill, mostly west of the area mapped (pl. 20), were made only for mining gold and copper.

\section{ROCKS}

The quicksilver deposits at Punitaqui are in the Porfiritica formation, near an intrusive contact with a granodiorite facies of the Andean diorite complex. The rocks there assigned to the Porfiritica formation differ from the predominantly volcanic rocks that represent the formation in most places, in that they include a large proportion of

18 Götting, A., Die Erzgänge zu Punitaqui in Chile, mit besonderer Berucksichtigung der Zinnoberführenđen Lagerstätten: Zeitschr. prakt. Geologie, vol. 2, pp. 224-230, 1894. Claro Montes, J. L., Compañía Minera Punitaqui : Bol. Minero, vol. 53, pp. 1262-1263, Santiago, Chile, 1941. Ayala Oliva, Jose, Estudio sobre la posibilidad de mejorar el rendimiento en la explotación de la mina de la Sociedad Anónima Compañia Minera Punitaqui. Unpublished thesis, University of Chile, Santiago, 1943.

$890880-50-2$ 
intrusive porphyry and are metamorphosed by the granodiorite. They are in part metamorphosed to a chloritic rock, some of which is so well foliated as to constitute a schist; at least a little of the schist was clearly granitized. Some rocks that are not part of the Porfiritica formation, as aplite and a dark facies of the grandiorite forming irregular dikes, were not in all places distinguished from the Porfiritica formation on the areal map (pl. 20).

The Porfiritica formation here contains thin layers of limestone, which appear to be lenticular, judging from the fact that where outcrops have come to an end there is no limestone float in line with them. Where exposed the limestone layers are mostly about 2 meters thick, but in a few places they bulge out to a much greater thickness. They strike nearly north, and their dips range from $45^{\circ} \mathrm{W}$. in the central part of the area, south of the Los Mantos mine, to approximately $90^{\circ}$ in the northern part. The limestone has been metamorphosed in widely varying degree, some of it being only a little bleached, whereas some has been altered to a massive garnet rock, which is well exposed northeast of the quarries at Los Mantos and in the saddle north of Culebra adit. (See pl. 20.)

Lamprophyre dikes, only 1 or 2 meters thick, are continuous within the Los Mantos vein underground as well as in the Porfiritica formation and in the granodiorite at the surface. Those seen underground all dip steeply west, but in the granodiorite at the surface some are flat lying and others are vertical. Parts of them, including apophyses with fine-grained margins, follow joints in granodiorite. 'The dikes were not all mapped; those in the small basin 300 meters northeast of Pique $2 \mathrm{~A}$ and on the hillside 250 meters southwest of the Culebra adit are not shown on the geologic map of the area. The original composition of the lamprophyre in the Los Mantos mine was not determined, for the rock is now highly chloritized and albitized.

The principal intrusive rock is a typical biotite-hornblende granodiorite containing many dark inclusions. As seen in thin section, it consists predominantly of plagioclase; orthoclase probably makes up somewhat less than a third of the volume. It contains a moderate quantity of quartz, rather abundant hornblende and biotite-the latter partly altered to chlorite and epidote along cleavages-and accessory sphene, magnetite, and apatite.

\section{STRUCTURE}

The outstanding structural feature of the district is a zone of faulting and minor shearing that was traced intermittently from the northern to the southern end of the area mapped (pl.20). It is marked by pockets and streaks of a peculiar, fine-grained fault breccia, consisting of ground-up fragments of rocks of the Porifiritica formation, of 
granodiorite, and of vein material. The fragments are in many places drawn out into bands, giving the breccia somewhat the appearance of weathered gneiss. Many of the grains are sand size, and others range from clay to pebble size. In some places the breccia has irregular, jagged, or blocky boundaries as if it had been squeezed or injected among joint blocks. This kind of breccia forms a distinctive and persistent feature of the main shear zone, having been traced from the workings north of the Culebra adit, through the adit itself, into the Los Mantos mine where it is seen on every level. It was also traced through the Champurria, Delirio, and Republicana mines in the southem part of the district. In the Azogues mine, on the other hand, and in many other workings east and west of the central zone the faults are not marked by this type of breccia.

The sort of breccia that has been described as characteristic of the major fault zone was formed later than most of the mineralization that produced the ore deposits. Some earlier shattering and brecciation occurred in this zone, however, before the vein minerals were deposited, as shown by remnants of breccia partly replaced by quartz. The early shattering provided good conduits for the ore solutions and determined the location of the veins. Faulting continued during the mineralization, producing a complex structure in the wide vein of the Los Mantos mine. Some parts of this vein contain loose fragments, and fragments that are but partly recemented. The same condition may be observed in the Delirio mine.

The main fault zone as a whole strikes about N. $20^{\circ}$ E. Its dip changes from place to place and varies with depth, being roughly vertical in the northern part of the area, about $60^{\circ} \mathrm{W}$. in the upper part of the Los Mantos mine but nearly vertical on the lowerst level, and between $65^{\circ}$ and $70^{\circ} \mathrm{W}$. in the Delirio-Republicana mine, at the southern end of the district.

In the southern part of the Los Mantos mine the main fault zone sends off a major branch, diverging eastward from the main zone at an angle of about $20^{\circ}$. This branch, which has been called the Cernícalo fault, crops out between two of the large quarries. It is marked by a vertical fault zone a few meters wide. Although it is somewhat mineralized, no ore of importance has been found along it at depth. The area contains many other faults, associated with gold-copper veins, but the Azogues fault, explored in the Azogues mine, is the only one of these minor ones that contains mercury minerals.

It is somewhat difficult to make out any systematic pattern in the faults for the region as a whole. Detailed underground mapping, however, in such places as the 170 level of the Los Mantos mine, reveals a fairly regular local pattern of fractures and veins (pl. 21). The bulging or abrupt widening of the vein where it bends in the southern 
part of the mine fits the pattern made by a shear couple producing tension there at successive periods during the mineralization. The bulge appears in two places on the 250 level (pl. 22). The same tendency for the mineralized zone to widen where horizontal shearing was translated into tension at a bend was observed during the detailed mapping of the Delirio mine, specially on the Socavón level (pl. 27). This evidence that the ore had a tendency to form on abrupt, even though minor, bends in the major shear zone may be useful in exploring for new ore shoots.

This shearing of course antedated the first mineralization, as it provided channels for the passage of solutions and prepared a favorable host rock; it continued during the deposition of the vein material. Shearing that caused relative southward movement on the west side displaced the vein horizontally. The effect, as seen in plans and sections (pls. 21, 22, and 23), may resemble the effect of either normal or reverse faulting, depending on the angle at which the faults intersect the vein. Lack of key beds makes it difficult to interpret the displacements, which had been interpreted as the result of hinge faulting. ${ }^{19}$ Further indication of postvein horizontal movement is the peculiar nose-shaped thrust fault, dipping northward, at the crosscut between the 2A and Maestro shafts on the 170 level of the Los Mantos mine (pl. 21). The northern block overrode the southern.

The theory that these structures are due to horizontal southward displacement of the western side of each of several fractures, was extrapolated to the southern part of the district and used in explaining the difference between the actual position of the vein on the 370 level of the Champurria mine and the position that would be indicated by projecting the same vein up to that level from the Socavón level of the Delirio mine (pls. 26 and 27). It was also applied, tentatively, to interpretation of details in the Delirio-Republicana mine, as shown in the maps and sections (pl. 27).

Another major structure of the region is the intrusive contact of the granodiorite with the Porfiritica formation. The main contact lies east of the veins and dips in general about $60^{\circ}$ to $65^{\circ} \mathrm{W}$. (pl. 23), either almost parallel to the principal veins or at a lower angle. A large protruberance from the batholith, seen in the northeastern parts of the 170 and 250 levels of the Los Mantos mine (pls. 21 and 22), and also on the surface 100 meters northeast of Pique 2A (pl. 20), accounts for the locally gentle dip of the contact in sections $A-A^{\prime}$ and $B-B^{\prime}$. (See pl. 23.) Small offshoots of granodiorite are exposed 200 meters east of the Culebra adit, also in the Azogues mine, in the adit on the 330 level of the Los Mantos mine, and in some of the explora-

\footnotetext{
19 Ayala Oliva, Jose, Estudio sobre la posibilidad de mejorar el rendimiento en la exploitación de la mina de la Sociedad Anónima Compañía Minera Punitaquí. Unpublished thesis, University of Chile, Santiago, 1943.
} 
tion workings of the Los Mantos mine. (See pls. 24 and 25.) How the veins change on entering granodiorite, a question that is of serious practical concern to the miners, has not been determined. The prevailing opinion is that they change for the worse, because at the surface the Porfiritica formation contains many ore-bearing veins and the granodiorite contains almost none.

\section{MINERALS}

The ore minerals and the minerals associated with them were discussed above insofar as they represent the characteristics of the Chilean quicksilver deposits in general. Only the distinctive mineralogical features of particular deposits are considered below.

Coarse-grained early calcite in large quantity is practically restricted to the part of the Los Mantos mine south of the main shafts. Much smaller masses were seen in veins in the Trinitaria workings not far west of the Los Mantos mine, and fragments of similar calcite were found in the breccia exposed in the Culebra adit. The origin of the calcite is controversial. The most obvious explanation is that the hydrothermal solutions dissolved the material on crossing lenses of limestone in the Porfiritica formation, and redeposited it in the vein. Nothing indicates how far the calcium-bearing solutions traveled. Another possible explanation of the origin is that the calcite is limestone recrystallized in place by contact metamorphism, and still another is that the calcite is of magmatic origin. The nearest observed outcrops of limestone include the highly metamorphosed mass at the quarries, and thin beds of limestone 400 meters south and 1,300 meters north of the quarries. The masses of calcite at the vein contain no garnet or other metamorphic silicate minerals, which are conspicuous in outcrops of metamorphosed limestone, and the extremely coarse texture of some of the calcite is far different from the texture of the limestone that has been seen at the surface, whatever its grade of metamorphism. It therefore seems most reasonable to regard the calcite in the vein as being a hydrothermal deposit derived from limestone, its limited distribution being explained by supposing that it was deposited only where the solutions passed through limestone occurring nearby.

Magnetite and specular hematite are two other minerals that are plentiful at Punitaqui but lacking in most other Chilean quicksilver deposits. Hematite is conspicuous in the Azogues and Los Mantos mines. In the Los Mantos mine granular cinnabar is associated with some of the hematite at depth, and powdery cinnabar accompanies the hematite in the oxidized zone at the Azogues mine. The occurrence of hematite and magnetite at Punitaqui suggests that the Punitaqui quicksilver deposits are nearer their magmatic source than are the other deposits. 


\section{LOS MANTOS MINE}

The Los Mantos mine is the property of the Compañía Minera Punitaqui, S. A., which officially calls it the Molle and Florida mine, because it was formed by uniting two mines that bore those names. As few people have ever heard the name on the company's books, the popular name, Los Mantos, is used in this report.

The Los Mantos deposit was worked for gold and copper during the latter part of the last century. Some of the old workings went down 115 meters from the surface, to a depth only 20 meters less than that of the lowest level in 1944. The mine lay idle for many years and had been considered virtually worked out.

The Compañía Minera Punitaqui was organized in 1935, largely with Chilean capital, and was staffed by Chileans. Modern equipment was installed, including a mill and flotation plant. The mine was developed systematically to mine gold and copper, and has been worked efficiently by modern methods. Equipment to recover mercury from the concentrates was installed in 1940, and production of mercury started the following year. A detailed account of the treatment of quicksilver ore at Punitaqui, and the equipment used, was published by Sr. Ricardo Fritis. ${ }^{20}$

More than 10,000 meters of workings were driven during the period $1937-43$, according to the annual reports of the company. ${ }^{21}$ The mine has four principal levels, at intervals of approximately 40 meters, the longest is about 1,000 meters. The levels are named according to their altitude in meters above sea level, as measured from a bench mark whose altitude was determined approximately by aneroid. The lowest is the 170 level, which is 145 meters below the collar of the $2 \mathrm{~A}$ shaft. The mine is worked by means of two main shafts, the Pique Maestro for ore haulage and the Pique 2A for communication. The highest level, the 290 , has been largely inaccessible since a severe earthquake in 1943, which caused much of it to cave. The distribution and extent of the workings are shown in plates $21,22,23$, and 24.

The principal workings exploit a massive, complex vein in the Porfiritica formation. The vein is 20 to 30 meters wide but in some places attains a width of 50 meters, and contains ore shoots 10 meters in average width. One of the stopes in the southern half of the 250 level is 200 meters long. The vein has been mined almost continuously over a maximum length of 500 meters on that level. Good ore, but in shoots somewhat shorter and narrower than those found above, was exposed on the lowest level in 1944.

\footnotetext{
${ }^{20}$ Fritis, Ricardo, La producción de mercurio en Chile: Anales Primer Congreso Panamericano de Ingeniería de Minas y Geologia, vol. 4, pp. 1626-1636, Santiago, Chile, 1942.

21 Compañía Minera Punitaqui, Sociedad Anónima : An. Rpts. 2-8, 1937-1943.
} 
As the general geology and mineralogy of the deposit have already been described, only a few details need be pointed out here. Quicksilver ore has been found only in the northern half of the Los Mantos mine, although traces of powdery cinnabar were seen in exploration adits in the southern part of the mine, and also in the Delirio mine far to the south.

Where not bounded laterally by gouge, the vein grades into replaced country rock, especially along the southern part of the western side of the Los Mantos mine. There is noteworthy gradation at the ends of the mine, particularly well shown at the north end of the 170 level, where the massive vein grades into silicified breccia, which in turn grades into partly replaced breccia. In some places, as at the south end of the 250 level, this gradation is obscured by a complex of faults and shear zones; however, the vein is dying out here and the faults probably have not cut off a large quantity of ore.

The vein dips rather consistently $60^{\circ}$ to $65^{\circ} \mathrm{W}$. near the surface, but it steepens with depth, especially at the bend in the vein in the southern part of the mine, where below the 210 level the vein is vertical and even slightly overturned. (See pl. 23.) Southward the hanging wall becomes more overturned, although the footwall, where bounded by a fault and a zone of breccia, returns to a steep westerly dip.

The exploration adits, shown in plate 25 , cut many faults and fault breccias, which can be considered part of the regional fault zone, but no vein more than a few centimeters wide was cut by the adits south of the Venero adit.

The company has followed an excellent exploratory program. Drifts have been run in both directions along the shear zone that carries the principal ore, crosscuts extend into the walls, and wellplaced adits cross the favorable zone south of the mine. Exploration northward seems more likely to be successful than exploration southward, because mercury ore is most abundant in the northern part of the mine and because the Azogues mercury mine lies to the northwest. The Culebra adit, moreover, which contains some cinnabar, is probably on the northern extension of the Los Mantos mineralized shear zone.

Reserves of measured quicksilver ore at any given time since the mining of mercury started in 1941 have amounted to about 1 year's production.

\section{CHAMPURRIA MINE}

The southern workings of the Compañía Minera Punitaqui, S. A., on the Delirio side of the divide (pl. 20) are called the Champurria mine. The older workings were inaccessible in 1944, but the exploratory workings called the 370 level were mapped (pl, 26). 
The adit exposes the contact of granodiorite on the east with the Porfiritica formation on the west. The Porfiritica here includes some quartz-epidote rock and some light-colored, altered rock that appears tuffaceous. The fine-grained breccia characteristic of the long shear zone is conspicuous. (See pl. 26.)

About 38 meters from the portal there is a stringer containing earthy cinnabar and copper stain, which corresponds to the mercurybearing east vein in the nearby Delirio mine. The main quartz vein is about 3 meters wide at the southern end of the drift, but narrows northward and pinches out in postmineral breccia at the northern end of the drift; and it is lost, also, in this breccia before reaching the surface. No cinnabar was seen in this vein. The mapping of the structure, including faults, breccia, and veins, beyond the southern end of the workings, represents a free interpretation, partly based on the projecting of structures from the adjoining Delirio mine.

\section{AZOGUES MINE}

The Azogues mine, entered by a shaft 650 meters north of the Pique Maestro of the Los Mantos mine (pl. 20), is an old quicksilver mine of the district, which the Compañía Minera Punitaqui, S. A., leased in 1937 from the owner, Doña Amalia Aldunate viuda de Beaugency, and reopened for exploration during the following years. In 1944 the shaft, a drift 35 meters below the collar, a crosscut midway along the drift, and parts of the stopes above and below the drift were accessible and were mapped with the able assistance of José Ayala. (See fig. 40.)

The shaft, and the drift for 25 meters, are in moderately fine grained granodiorite, rich in biotite, which lies in contact with andesite porphyry of the Porfiritica formation. The remainder of the workings are in the Porfiritica formation, except where flanked by a lamprophyre dike.

The vein that was explored along the drift was struck 40 meters north of the shaft, and was followed northward for about 100 meters where it was pinched out by faults. A short distance beyond this point it reappears for a few meters, but it is concealed by caved workings about 175 meters north of the shaft. The vein, which dips $50^{\circ}$ to $60^{\circ} \mathrm{W}$., was controlled by a fault, along which there has been some postmineral movement. The minerals making up the vein are chiefly quartz, specular hematite, pockets of powdery cinnabar and some copper stain. Most of the cinnabar mixture is in cavities in the quartz, but some is in porous parts of hematite masses.

Cross stringers of quartz containing earthy cinnabar occur in the granodiorite within 5 meters of the contact, and others occur in the andesite porphyry. Near the beginning of the main crosscut eastward is a complex of veins and faults containing rich pockets of earthy 


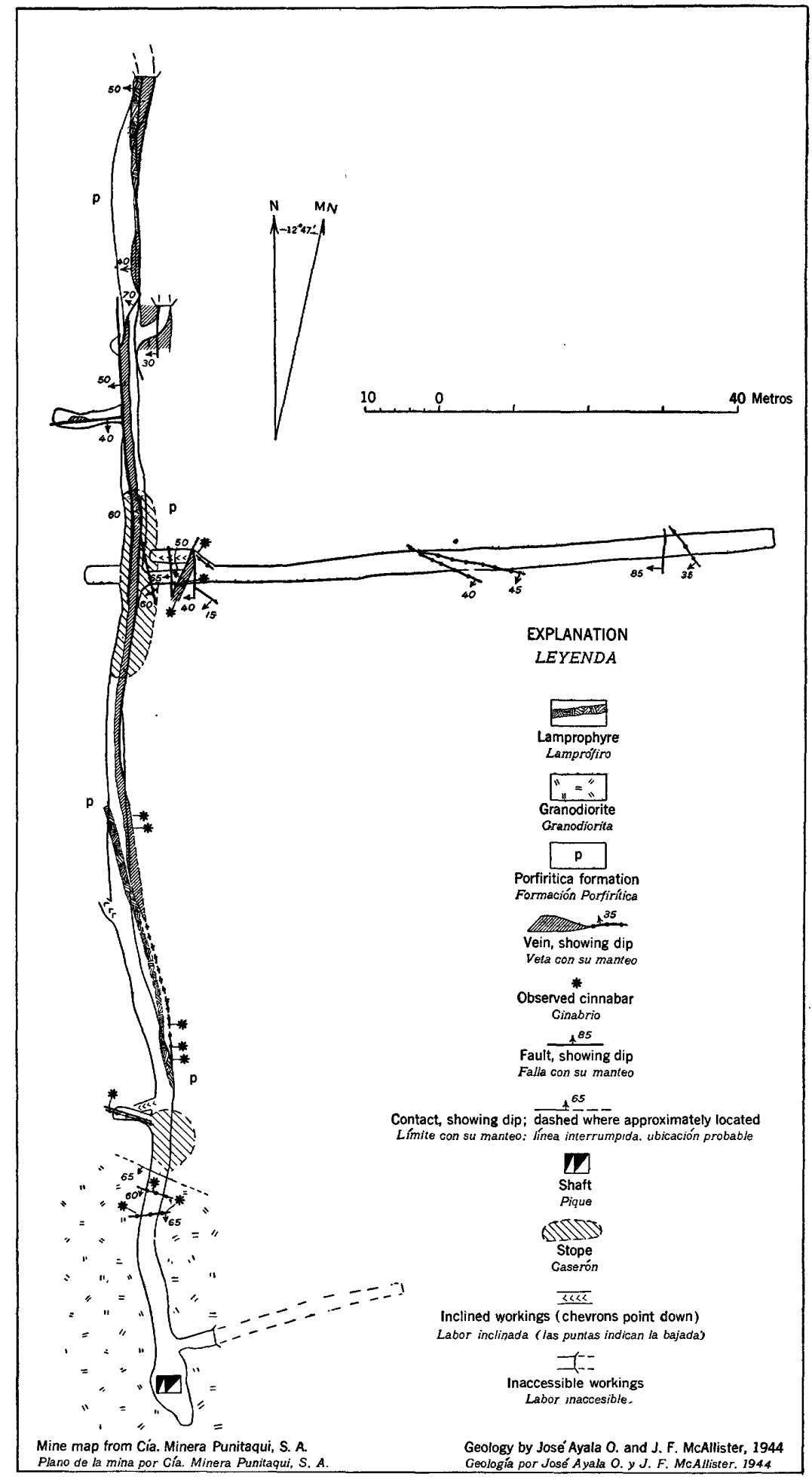

Figdre 40.-Geologic map of the main level, Azogues mine, Punitaqui, Chile. 
cinnabar which yielded some of the highest assays. This crosscut is in unaltered rocks of the Porfiritica formation, in which there are a few veins, 2 to 10 centimeters wide, of quartz, hematite, and clay, with some copper stain. No cinnabar was seen in them although samples across some of them, taken by the Compañía Minera Punitaqui, S. A., assayed 0.3 percent mercury.

The main vein is in general about 60 centimeters thick and is probably a fault breccia thoroughly replaced by quartz and hematite, but it includes some veins of quartz about 3 centimeters thick that may be fissure fillings. The total width of the zone of mineralization, including gouge as well as veins, is about 150 centimeters.

Samples ${ }^{22}$ taken along a 35 -meter stretch, beginning 10 meters north of the long crosscut, assayed 0.13 to 0.38 percent mercury. The best samples came from the last 7 meters of the strip, for which the average was about 0.3 percent mercury; the remainder averaged about 0.17 percent. Samples representing about 10 meters of the vein just south of the caved part averaged about 0.3 percent over a width of 27 centimeters. The highest gold assay was 5.5 grams per metric ton, but the usual gold content was not much over 1 gram per ton.

An inclined winze 37 meters north of the shaft leads to small stopes that contain remnants of excellent crystalline cinnabar ore, which seemed to be present at rolls in the vein.

The Azogues vein and fault flatten to $35^{\circ}$ before reaching the surface roughly 60 meters northeast of the shaft. Their outcrop on the hillside is marked by a line of old workings, including a caved adit near the foot of the hill. What is probably the same vein and fault zone is exposed in shallow pits on the nose of the hill, and poor, discontinuous exposures continue for 500 meters farther to the top of the high ridge. Near the top, a little north of the mapped area, there are many inclined workings along the vein, which is said to contain mercury minerals in that place. The changes in the course of the outcrops between the Azogues mine and the top of the ridge are largely the effects of topography.

\section{CULEBRA ADIT}

The Culebra adit, which belonged in 1944 to the Compañía Minera Santa Inés, is 320 meters east of the Azogues vein and 1,250 meters northeast of the main shaft of the Los Mantos mine. (See pl. 20.) It follows the principal fault zone of the district for about 160 meters. Shallow workings trace the zone up the hillside from the adit to the saddle, where a strip of breccia only about 5 meters wide is exposed in a trench. There are many other workings in the north slope beyond,

${ }^{22}$ Sample data from the Compaña Minera Punitaqui, S. A., 1944. 


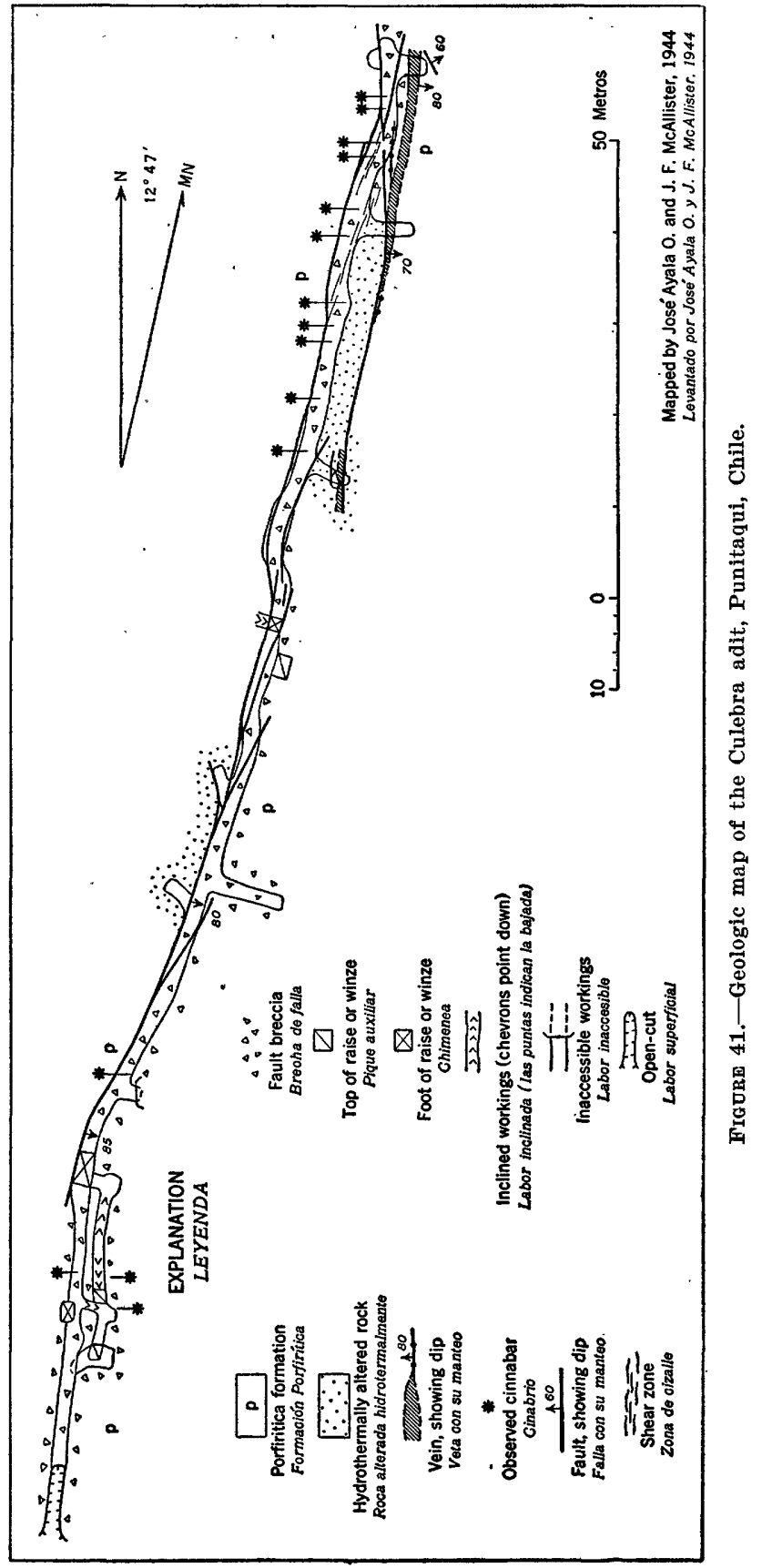


outside the mapped area. Gold ore had been mined from a few small workings opening into the Culebra adit. In 1944 the dumps were being sorted by hand for gold ore.

The adit (fig. 41) is in the Porfiritica formation, which here includes some fine-grained chloritic rock grading into schist but consists mainly of porphyritic rocks. Fault breccia forms both walls of the adit in the outer 30 meters, beyond which the west wall is a slickensided and grooved fault surface that limits the breccia. This surface in general is very steep, dipping $80^{\circ}$ to $85^{\circ} \mathrm{E}$., and has some fluting that plunges $50^{\circ} \mathrm{S}$. The breccia is 5 to 10 meters wide for 75 meters from the portal, and then pinches down to a width of 2 or 3 meters. The breccia is partly postmineral, for it contains fragments of vein quartz, hematite, chalcopyrite and pyrite in quartz, coarse calcite, and altered porphyry. Halfway along the adit, and also near the face, there are pockets of the breccia with distinctive sand-size particles, that in the Los Mantos mine characterize the major shear zone and are not found in neighboring faults. Two short crosscuts extending eastward from the last 20 meters of the adit cut a vein of quartz and hematite about 1 meter wide. The fissures in the shattered rock nearby are filled with hematite.

The earthy mixture of cinnabar and oxides occurs at the places indicated on the map (fig. 41). It is usually associated with copper stains, although locally red powder without copper minerals fills or lines cavities in quartz, or forms streaks and pockets in clay.

\section{DELIRIO-REPUBLICANA MINE}

The Delirio mine and associated workings, at the southern end of the Punitaqui quicksilver district (pl. 20), were reopened by the Compañía Minera Delirio de Punitaqui to mine gold. Accessory cinnabar was found, but the ore has not been treated to recover the mercury.

The workings in 1944 consisted of the old Delirio mine, which had two levels, accessible by way of the Delirio shaft and an adit, and isolated workings opening from two inclined shafts, the Pique Norte and Pique Sur of the Republicana mine. Levels extending from these shafts were driven at the same altitudes, and they also correspond with levels in the Delirio mine, the company's intention being to connect all the levels into one system. (See pl. 27.)

The mine is in the Porfiritica formation, west of an intrusive contact with granodiorite that dips about $60^{\circ} \mathrm{W}$. In several places the workings cut massive epidote-quartz rock, which may represent calcareous layers in the Porfiritica formation that were completely metamorphosed. The granodiorite was exposed on the first level, about 35 meters below the surface, in the crosscut to the Delirio shaft (pl. 27).

The veins are in a zone of intensely altered rock, which is bounded by faults on the east side and also along parts of the west side. In 
some places, for example southwest of the Delirio shaft (pl. 27), the zone is as much as 60 meters wide, but it narrows to 5 or 10 meters at the south shaft (Pique Sur) of the Republicana workings. The entire altered zone has been regarded by the operators as vein material, principally because the stoping limits are economic rather than mineralogic. It was found possible, however, to map the boundaries of the quartz-limonite or sulfide bands within the zone of intensely altered and stained rock. If these bands are regarded as veins, there are two distinct veins in the Delirio mine. The wider vein, which is on the western side of the mine, is somewhat crescent-shaped, its width varying from 5 meters to 20 meters. The eastern vein, in general 1 to 2 meters wide, is somewhat discontinuous, and some parts of it overlap. The zone as a whole, as seen in the levels extending from the Pique Norte and the Pique Sur of the Republicana workings, thins southward, as the individual veins do also. (See pl. 27.) Where they are oxidized, the veins consist mainly of shattered quartz cemented with massive limonite and in places heavily stained with copper carbonates. Farther down, the quartz contains pyrite and chalcopyrite. In the Delirio part of the mine, all but a few specks of the cinnabar observed was in the east vein and in the fill of old workings along it. Most of it is in an earthy mixture with oxides, associated with malachite and azurite.

The controlling structure at the Delirio-Republicana mine is a belt of faults and shear zones, which as a whole has a persistent trend and dips about $60^{\circ} \mathrm{W}$., but which is complex in detail. The structural history is much the same here as at the Los Mantos mine: fracturing prepared channels for hydrothermal solutions, which altered the rock and introduced the vein minerals; then fracturing probably continued during and after the deposition of the veins, shattering much of the quartz. The structure has been interpreted as showing that the horizontal component of movement was large relative to the vertical component, and that the west side moved relatively southward. Premineral movement in that direction provided conditions favoring the formation of bulging, crescent-shaped veins. Postmineral movement in the same direction would explain the offset of the veins between the Delirio and Champurria mines. (See p. 376.)

Mercury minerals occur only in narrow and short parts of the veins, earthy cinnabar being scattered over a width of 1 to 2 meters for lengths of 25 or 30 meters. The ore is of such low grade that even when it commands a high price, mercury cannot be recovered at a profit except as a byproduct from gold-copper concentrates. The two places at which mercury minerals are most abundant are the southern part of the east drift on the first level of the Delirio mine (pl. 27) and the northern end of the west drift on the second level of the Pique 
Norte part of the Republicana workings. According to the Compañia Minera Delirio de Punitaqui, samples from the first locality assayed 0.06 to 0.44 percent in mercury, but usually between 0.2 and 0.3 , and contained on the average 6.5 grams of gold, over assay widths of 0.8 to 2 meters. At the second locality, samples representing a length of 20 meters and an average width of 1 or 1.5 meters assayed up to 0.16 percent mercury but usually less than 0.1 percent; here also there was some gold, but in 1944 the ore was below the cut-off grade. This assay information concerns only the mercury-bearing parts of the mine, and does not deal with the ore shoots that were being mined primarily for gold. No mercury was being recovered in 1944 and no reserves of quicksilver ore had been calculated.

\section{HUANILLO}

\section{ALGARROBO MINE}

The Algarrobo quicksilver mine, in the Provincia de Coquimbo, is 10 kilometers by unimproved road southwest of the small settlement of Huanillo, from which it is 5 kilometers to the main road and 27 more to Ovalle. The total distance of 42 kilometers can be traveled by automobile in $1 \frac{1}{2}$ or 2 hours. The deposit is only about 20 kilometers in a direct line east of Punitaqui.

The mining property belonged in 1944 to the Compañía Minera Monte Patria, which had undertaken a program of rehabilitation. By May of 1944, exploration had gone down 100 meters from the surface and extended over a longitudinal distance of 60 meters. The workings are somewhat erratic and steep, and follow a zone of mineralization that generally is vertical, though deviating, for 55 meters from the surface, but dips northwest in the remaining 45 meters. The strike of the zone is persistently N. $40^{\circ} \mathrm{E}$.

The rock of the surrounding region is chiefly granodiorite, and some aplite. The granodiorite is medium-grained, rather light colored, and contains many dark inclusions. It consists of abundant plagioclase, considerable orthoclase and quartz in smaller grains, augite, and chlorite probably derived from biotite. Most of the rock in the mine is altered granodiorile. Near veins, thorough alteration to chlorite, calcite, epidote, sericite, and clay minerals obscures the original nature of the rock.

The mineralization followed steep fractures. The movement on them was probably small, and as shown by grooves, horizontal at least in part. A quartz vein 10 to 20 centimeters thick follows a thoroughly argillized zone that is 1.5 meters wide in places. Some argillized material contains specks and lumps of earthy cinnabar. At the bottom of the mine the vein is 3 or 4 centimeters thick, strikes N. $40^{\circ}$ E. and dips $65^{\circ} \mathrm{NW}$. The vein minerals are early quartz, tab- 
ular barite, later quartz interstitial between the barite grains and eating into some of them, a little pyrite, finely crystalline cinnabar replacing quartz, coarse grains of cinnabar in small vugs, earthy cinnabar mixtures associated with copper carbonates, and limonite. There are probably some small grains of mercurian tetrahedrite. The ore differs from that at Punitaqui in containing barite and in being free from specular hematite; in these respects it is similar to most of the deposits described below. Its occurrence in granodiorite is an unusual feature.

\section{IILAPEL}

AZOGUES MINE

The only known quicksilver deposit in the Departamento de Illapel, Provincia de Coquimbo, was not examined for this report. It is about 20 kilometers in a straight line north of Illapel, and about 14 kilometers northwest of Aucó station on the longitudinal railroad, north of Illapel.

Little ${ }^{23}$ described the deposit in only a few lines as ". . . a hightemperature vein in granite. The oxidized zone, containing malachite, azurite, and cinnabar, was worked for mercury and copper."

A report written in 1940 by Ing. Carlos Chait W. for the Caja de Crédito Minero of the Chilean Government contains information that is summarized as follows:

Some old workings, consisting of three mines, were originally worked for copper, and the mercury minerals were left in the dump. The main vein, 27 to 45 centimeters wide and traced for 50 meters, is composed of quartz, malachite, azurite, chalcocite, cinnabar, and in some places abundant limonite. A few samples from cuts about 50 centimeters long assayed slightly over 0.2 percent mercury, and contained a little gold, silver, and copper. Samples from another vein assayed about 0.1 percent mercury. In 1940 there was one retort, with a capacity of 100 kilograms.

\section{ANDACOLLO}

In the Andacollo district, Provincia de Coquimbo, there are two quicksilver mines, the Dichosa and the Merceditas, both of which are south of the gold district and town of Andacollo. The town is reached by a good road, which leaves the longitudinal highway and railroad at Andacollo station south of Coquimbo. The two quicksilver mines are separated by a spur and have no direct connection by road. As mentioned previously, the first discovery of mercury in Chile was made in this district in 1778. Ore was mined intermittently, depending on the mercury market and local requirements. The mines were idle at the time of the examination. Domeyko studied the ores in the latter part of the last century, and was particularly interested in the

${ }^{23}$ Little, J. M., The geology and metal deposits of Chile, p. 162 New York, Branwell Co., 1926. 
mercurian tetrahedrite and its oxidation product, the earthy mixture of cinnabar and oxides. The mines, when examined in 1944, were the property of Sr. Tomás Whittle, who acquired them in 1916. As in most small idle mercury mines, the ore remaining in sight was negligible.

\section{DICHOSA MINE}

The mercury deposits at the Dichosa mine (the ancient iron mine) are in purplish-brown, porphyritic hornblende andesite of the Porfiritica formation. This rock is clearly extrusive and, away from the part altered by vein solutions, contains cloudy feldspar phenocrysts. About 45 meters southeast of the north portal, there is an outcrop, 2 or 3 meters wide, of limestone striking N. $50^{\circ} \mathrm{W}$. and dipping $60^{\circ} \mathrm{SW}$. (magnetic north). Brecciated cherty rock having about the same attitude crops out 30 meters east of the limestone. This outcrop may be a southern extension of a large mass of highly silicified rock that extends for 30 meters north of the round open cut and is about 10 meters wide, but the rock surrounding it is concealed by mine dumps and surface rubble.

The north adit, extending eastward into the hillside, passes for 3 meters through porphyritic rock dipping west, then through several meters of rock that is possibly a much-altered tuff, then through 5 meters of breccia whose original nature has been obscured by weathering and other alteration, and then into silicified rock as far as the first drift (pl. 28). This drift follows a quartz vein 5 to 10 centimeters thick, which contains limonite, earthy cinnabar, and copper stain, and which is bordered by shattered silicified rock and gouge. Raises from the drift lead to small stopes, the backs of which in 1944 were about 5 meters above the adit level and revealed good showings of earthy cinnabar. About 10 meters beyond the drift the adit crosses a network of fractures in which a short inclined winze exposes some earthy cinnabar. The adit is accessible for 9 meters more to the point, 42 meters from the portal, where it joins another drift that follows a mineralized fault zone. This zone is parallel to the first and likewise contains earthy cinnabar, limonite, and quartz. This zone and the inclined winze lie under the large, circular open cut. (See plate 28.)

The portal of the south adit is about 180 meters east-southeast of the north adit and 15 meters lower. This adit, accessible for 90 meters, is entirely in prophyritic andesite and clay derived from it. Twelve meters from the portal the adit reaches a main fault and turns slightly to follow it; there the entire width of the adit is occupied by clay along the fault and its subsidiary fractures. Some of the clay is very light colored and may be largely hydrothermal rather than true fault gouge; other parts of it are gray. Thirty meters from the portal a stope about 8 meters long and 1.5 to 3 meters wide has been put up from the 
adit, but only traces of earthy cinnabar remain in the adjacent clay. Eighty meters from the portal, in the white clay, a vein of quartz and barite 5 to 10 centimeters wide, contains considerable earthy cinnabar and azurite for a length of 10 meters. A shallow winze follows the stringer down for 3.5 meters. The adit is caved a short distance beyond, directly under the southeast end of deep cuts at the surface (pl. 28).

\section{MERCEDITAS MINE}

The mineral deposits of the Merceditas mine, in Quebrada La Jarilla, are in porphyritic andesite flows, volcanic breccia, and tuff, all of which belong to the Porfiritica formation. (See pl. 29.) The lowest level is in andesitic volcanic breccia, the next level is in slightly undulating, stratified tuff, and the highest workings are partly in tuff and partly in overlying andesite. Large masses of silicified rock crop out prominently near the workings, especially to the northeast. Some of the silicified rock was originally a volcanic breccia, but some of it has been so completely silicified that its original nature is not apparent.

Mineralization was controlled by an essentially vertical zone of faults. The grooves on the fault surfaces are nearly horizontal or plunge $15^{\circ}$ to $25^{\circ} \mathrm{W}$., showing that a large component of movement, if not the dominant one, was horizontal.

The veins, which consist mainly of quartz and barite, contain conspicuous earthy cinnabar, azurite, malachite, and limonite, and in their unweathered interior parts, pyrite and mercurian tetrahedrite. The widest parts of the veins in place are about 60 centimeters wide, but a zone as much as 4 meters wide has been stoped. Some showy rock has been formed by migration of red cinnabar and blue azurite into networks of minute fissures in white rock. In some druses, powdery cinnabar coats crystalline azurite, but in general it is difficult to determine which mineral is the later. Some veinlets of malachite cut the red powder. Some of the mercurian tetrahedrite is rimmed and veined with the powdery cinnabar mixture.

Selective silicification and mineralization of tuff beds near their contact with andesite seem to have migrated out from the vertical zone, forming hard layers in the gently undulating beds. As these layers are resistant to weathering, they preserve fresh mercurian tetrahedrite.

\section{DOMEYKO}

\section{LUISIANA MINE}

The Luisiana property is near the southern border of the Departamento de Vallenar, in the Provincia de Atacama. It is reached by an unimproved road about 10 kilometers long, extending west from Cachiyuyo, south of Domeyko on the longitudinal highway and railroad.

$890880-50-3$ 


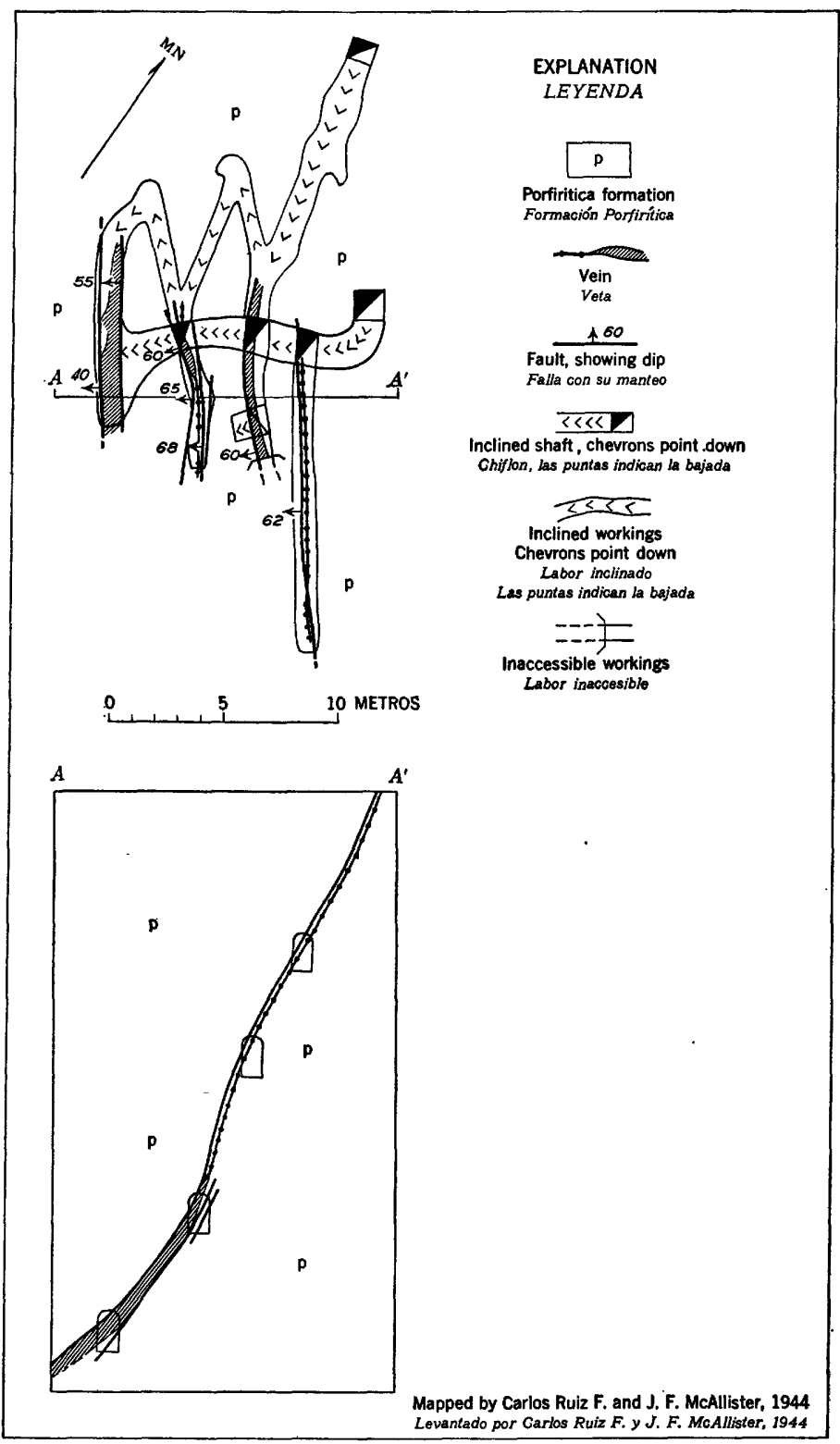

FIGURE 42.-Geologic map and section of the Luisiana quicksilver mine, Domeyko, Chile.

In 1943 to 1944 , according to the operator, Sr. Meyenberger, ${ }^{24}$ about 100 tons of quicksilver ore was mined. It was treated in two retorts of 100-kilogram capacity.

The Luisiana quicksilver mine is in the Porfiritica formation metamorphosed by an intrusive body of the Andean diorite complex, which

24 Oral communication July 2, 1944 . 
crops out about 600 meters to the east. The workings (fig. 42 ) follow a quartz vein striking $\mathrm{N}$. $35^{\circ} \mathrm{W}$. and dipping on the average $65^{\circ} \mathrm{SW}$, in hydrothermally altered rock. The ore mineral is cinnabar, in part visibly crystalline and in part powdery. Hematite and magnetite are common associates, and form stringers through the country rock, addition of iron apparently being the most characteristic feature of the contact metamorphism of the volcanic rocks. At the bottom of the workings in 1944, about 25 meters vertically from the surface, the quartz vein was only 5 centimeters thick, but the mineralized zone was nearly a meter wide. The solutions that altered the rock and deposited the vein minerals were controlled by a fault, which in some places splits into several branches. (See fig. 42.) The ore shoot seems to have been about 2 meters wide along the vein.

Mercury mineralization was not restricted to one place in the district. Several kilometers south of the Luisiana mine, the granular cinnabar occurs in veins of quartz and chalcedony several centimeters thick, in the Porfiritica formation.

\section{COPIAPO}

A series of quicksilver deposits, which for convenience are grouped loosely into districts, lie 35 to 80 kilometers south of Copiapó. They are described under the name of this well-known town partly because some of the district names are used also at other localities.

\section{Cerro blanco}

Mirador property.-The Mirador property, held in 1944 by Sr. Benedicto Toro, contains the only known quicksilver deposits in the Cerro Blanco district. The property is reached by a somewhat devious route, much of it over unimproved road; the distance is 125 kilometers from Copiapó by automobile and about 3 kilometers farther by foot trail.

The country rock is a part of the Porfiritica formation, consisting of purplish-brown andesite underlain by volcanic breccia. The andesite has cloudy feldspar phenocrysts. The breccia has been extensively but irregularly altered to greenish and reddish rock, some of it showing concentric diffusion bands. Granitic rock is exposed upstream but was not studied.

The geologic map (pl. 30) of the area shows the distribution of the veins and of the faults that controlled most of them. The mineralized faults in general strike N. $37^{\circ}$ to $40^{\circ} \mathrm{W}$. and dip $75^{\circ}$ to $80^{\circ} \mathrm{SW}$. Pits and trenches show vein minerals for about 500 meters along a fault. The largest workings are near the northwest end of the mineralized zone, where a steeply inclined shaft 18 meters deep follows a quartz vein 2 to 20 centimeters wide. The vein contains mercurian tetrahedrite, which weathers to the powdery cinnabar mixture, copper- 
stained and associated with limonite. The same minerals were seen at the bottom of the shaft, where the vein, there about 1 meter wide, is represented by a network of veinlets in altered rock. The same mineral assemblage was seen in the southeastern part of the zone. Sr. Toro burned 400 kilograms of hand-sorted ore taken from the southeastern trench in the ravine (pl. 30) and recovered 4.8 kilograms of mercury, showing that hand-sorted ore contained at least 1.2 percent of mercury.

Another vein was explored for 150 meters, starting from an outcrop in the Carrizo gulch about 250 meters northeast of the Mirador shaft and 115 meters lower. This vein contains the minerals described as occurring in the other veins; barite is prominent in the gangue.

\section{CERRo DEL FraILE}

Quicksilver deposits have been found at widely spaced intervals on the eastern and southern slopes of the Cerro del Fraile, which is a low range 55 kilometers in a direct line south of Copiapó, or about 75 kilometers by way of a road that goes up the Copiapó valley to the vicinity of Pabellón and then up a tributary. The mines are only 1,500 meters higher than Copiapó. Water is extremely scarce; the only sources of water noticed near the deposits are a small spring below the Negra mine and the shallow well at Quinta Toro, which supports the only settlement in the area.

Tres Hermanos mine.-The only producer at Cerro del Fraile in June 1944 was the Tres Hermanos mine, owned by the Toro family, and its production was merely a flask now and then. The quicksilver ore was mined from a lode, striking about N. $65^{\circ} \mathrm{E}$. and dipping $50^{\circ}$ NW., in porphyritic hornblende andesite of the Porfiritica formation. The lode is 80 to 100 centimeters wide, and the ore consists of veinlets of powdery cinnabar in the silicified parts of an argillized zone. The best ore is in a streak 40 to 50 centimeters wide, under silicified rock in the hanging wall. Copper stain and abundant limonite accompany much of the red powder. No coarsely crystalline cinnabar was seen. The only opening was a pit 7 meters deep, inclined about $50^{\circ}$.

Several hundred meters northeast of this first pit, powdery cinnabar is exposed in several very shallow prospect pits scattered along a line trending $\mathrm{N}$. $50^{\circ}$ to $60^{\circ} \mathrm{E}$. The line of pits extends about a kilometer farther northeastward and the distance between pits ranges from 100 to 550 meters.

Negra mine.-The Negra mine is about 3.3 kilometers up the Quebrada Negra by way of a trail that leaves the road to Copiapó at a place 3.3 kilometers from the Quinta Toro. According to local reports, the deposit had been worked by Herbert Jander of Copiapó and the Toro brothers, but the quantity of mercury recovered was not known.

The mineral deposit contains powdery cinnabar with copper stain and abundant limonite in rather porous quartz. The vein, 12 to 20 
centimeters wide, is in the Porfiritica formation and extends along a lamprophyre dike, 50 to 100 centimeters wide, which is much altered to clay. The dike is in the footwall of a fault striking N. $20^{\circ} \mathrm{E}$. and dipping $75^{\circ} \mathrm{NW}$. There are two shallow workings, within 18 meters of each other, on this vein, which crops out northeast of the pits for about 50 meters. The deepest part is about 8 meters below the surface and the greatest horizontal extent is 11 meters.

A grab sample from the vein zone, including material with visible powdery cinnabar, as assayed by J. J. Fahey of the Geological Survey, yielded only 0.09 percent mercury. The mercury content of the small quicksilver deposits exposed in abandoned workings in all the districts is believed to be similarly low.

Candelaria mine.-The Candelaria quicksilver property, owned by Mr. B. W. Ramsey, is on the southeast flank of the Cerro del Fraile, about 3 kilometers by trail from Quinta Toro.

The quicksilver deposits consist mainly of quartz stringers containing powdery cinnabar, associated with much limonite and a little copper stain, in zones of argillized rock of the Porfiritica formation. The Porfiritica formation in this region consists of volcanic breccia, tuff metamorphosed to a hornfelslike rock at the contact of intrusive andesite porphyry, and probably andesitic lava. Some powdery cinnabar occurs also along joints parallel to veins, and is disseminated through argillized rock. Irregularities of the workings suggest that there were pockets of higher-grade ore. The mineralizing solutions followed a zone of minor faults, which are nearly vertical but undulating.

The two largest workings with showings of cinnabar are at the northern end of the group. The northern one is a stope that plunges $40^{\circ} \mathrm{N}$. for 15 meters along an altered zone that strikes N. $30^{\circ} \mathrm{E}$. and dips $75^{\circ} \mathrm{NW}$. This zone is about 1 meter thick and contains quartz stringers as much as 5 centimeters thick which in general do not have sharp boundaries.

The other consists of a pit about 5 meters deep, from the bottom of which a drift extends 5 meters toward the south and an incline about 5 meters long plunges $40^{\circ}$ toward the north. In the west wall of the drift an undulating fault ranges in dip from $80^{\circ}$ E. to $80^{\circ} \mathrm{W} . ; 2$ meters south of the pit the fault swings west into the wall. Brilliantred powdery cinnabar was seen in veinlets and impregnating the argillized and somewhat silicified rock, which was deeply stained with limonite in a zone about 20 centimeters in maximum width but which narrows to 5 centimeters at a height of 2 meters above the bottom of the north trench.

Prospect holes in which no mercury minerals were seen follow a fault zone toward the south. In the first prospect, about 20 meters south of the cinnabar deposit, the fault strikes N. $32^{\circ}$. E. and dips 
$65^{\circ} \mathrm{NW}$. Other shallow prospects 25 meters farther south expose a complex zone of small faults, which are also barren as far as could be seen in a brief inspection. The same zone was followed to the top of the ridge, 30 meters farther, or about 75 meters from the observed cinnabar. On the ridge the zone strikes about N. $30^{\circ}$ E. and dips $65^{\circ} \mathrm{NW}$., parallel to a fine-grained dike and to a zone of alteration, roughly 40 meters wide.

East of this more or less continuous zone of alteration along faults are other shallow prospect holes in hydrothermally altered rock.

\section{SIERRA LA PLATA}

The quicksilver deposits in the Sierra la Plata lie within short walking distances of automobile roads from Copiapó. A graded gravel road extends $26.5^{\prime}$ kilometers up the Copiapó valley to the mouth of Quebrada de Cerrillos, which is traced by a poorer branch road. It is 12.4 kilometers up this road to the side canyon containing the Regalona prospect, and $\mathbf{1 4 . 3}$ kilometers to a trail leading to the Alianza mine. The surrounding country is almost devoid of vegetation and of readily available water.

Regalona prospect.-The Regalona property, about 2 kilometers up a side canyon of Quebrada de Cerrillos, within a few hundred meters of the limit of automobile travel, in 1944 belonged to Sra. Sara Plaza of Copiapó. It had been registered as a cobalt claim, at a time when interest in cobalt was booming locally. None of the mercury has been mined from the property.

Veins, whose outcrops are black with manganese oxides in some places and brown with iron oxides in others, lie in an area of hydrothermally altered andesite of the Porfiritica formation. As a result of the alteration, which produced silica, sericite, and kaolin, the rock contains light-colored patches stained in places with iron oxides. Late calcareous spring deposits consisting in part of coarse-grained calcite occur at a pit near a deposit of cinnabar. A short distance to the southwest, near some aplitic dikes, are large patches of coarse-grained metamorphic minerals such as scapolite, amphibole, and tourmaline.

Cinnabar was observed at two localities. The dump of a caved pit near the southern occurrence showed copper minerals in considerable amount, together with some visibly crystalline cinnabar and a powdery mixture of cinnabar and oxides, in a gangue of barite and quartz. Cinnabar was also seen in place about 115 meters farther east, in an iron-manganese vein that is probably a continuation of the one just mentioned.

Alianza mine.-The Alianza quicksilver mine is within a few hundred meters of a road by way of which it is 41 kilometers to Copiapó. According to the owner, Sr. Herbert Jander of Copiapó, ${ }^{25}$ the mine

${ }^{25}$ Oral communication, June 1944. 
produced 2,000 kilograms, or 58 flasks, of quicksilver between October 1942 and June 1943. The mine has an adit, of which only the outer 50 meters were accessible at the time of the examination. The vertical projection of the workings (fig. 44) shows that exploration was carried to a depth of 25 meters below the surface, and for a horizontal distance of 90 meters.

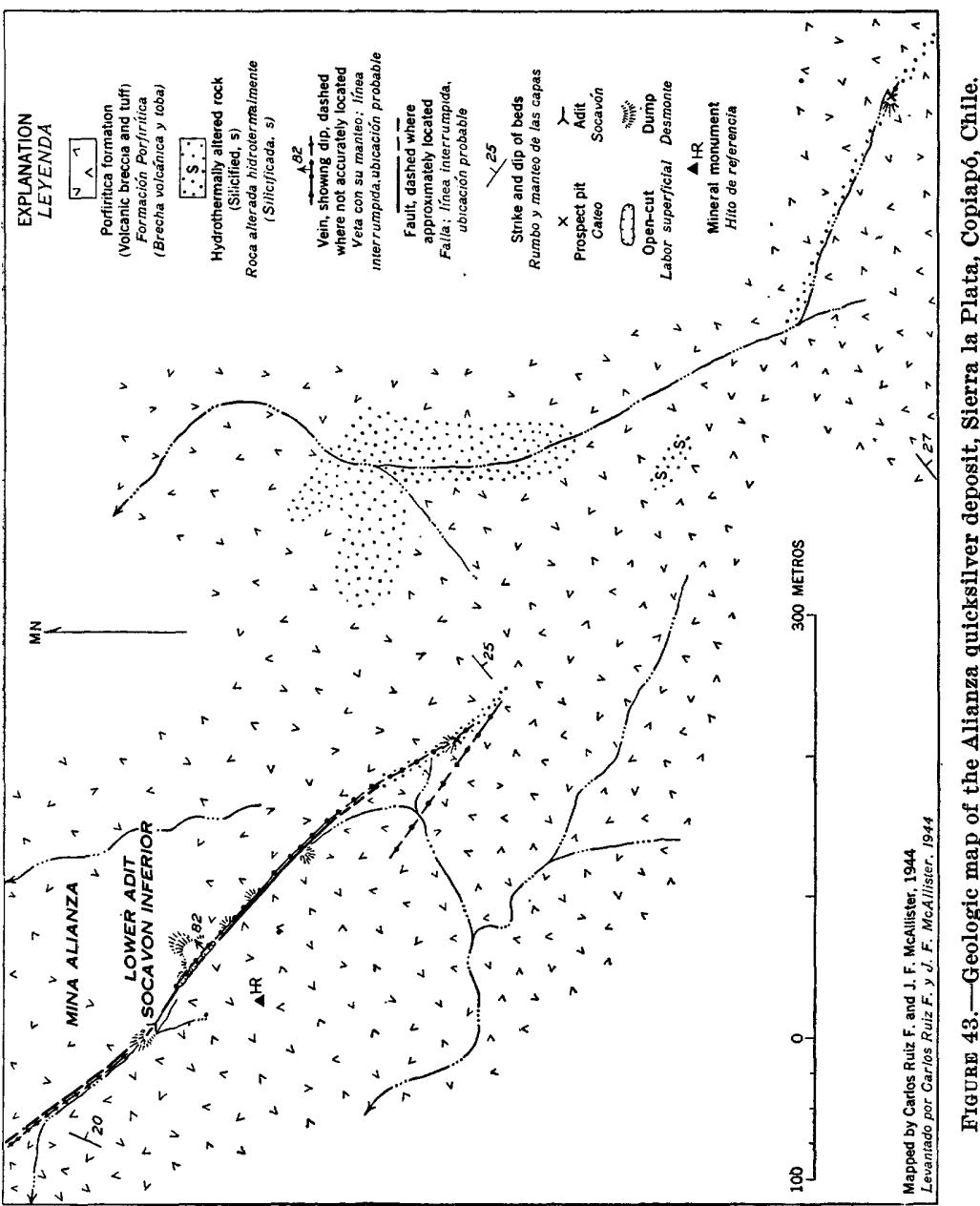

The rocks in the vicinity of the mine (fig. 43) belong to the Porfiritica formation; they consist of andesite in the northeastern part of the property, and of stratified pyroclastic rocks, ranging from tuff to fine-grained volcanic breccia, in the central and southeastern parts. The rocks are hydrothermally altered in conspicuous lightcolored patches, as a result of silicification, argillization, sericitization, and staining with iron oxides. These changes were superimposed 
396 GEOLOGIC INVESTIGATIONS IN THE AMERICAN REPUBLICS, 1949

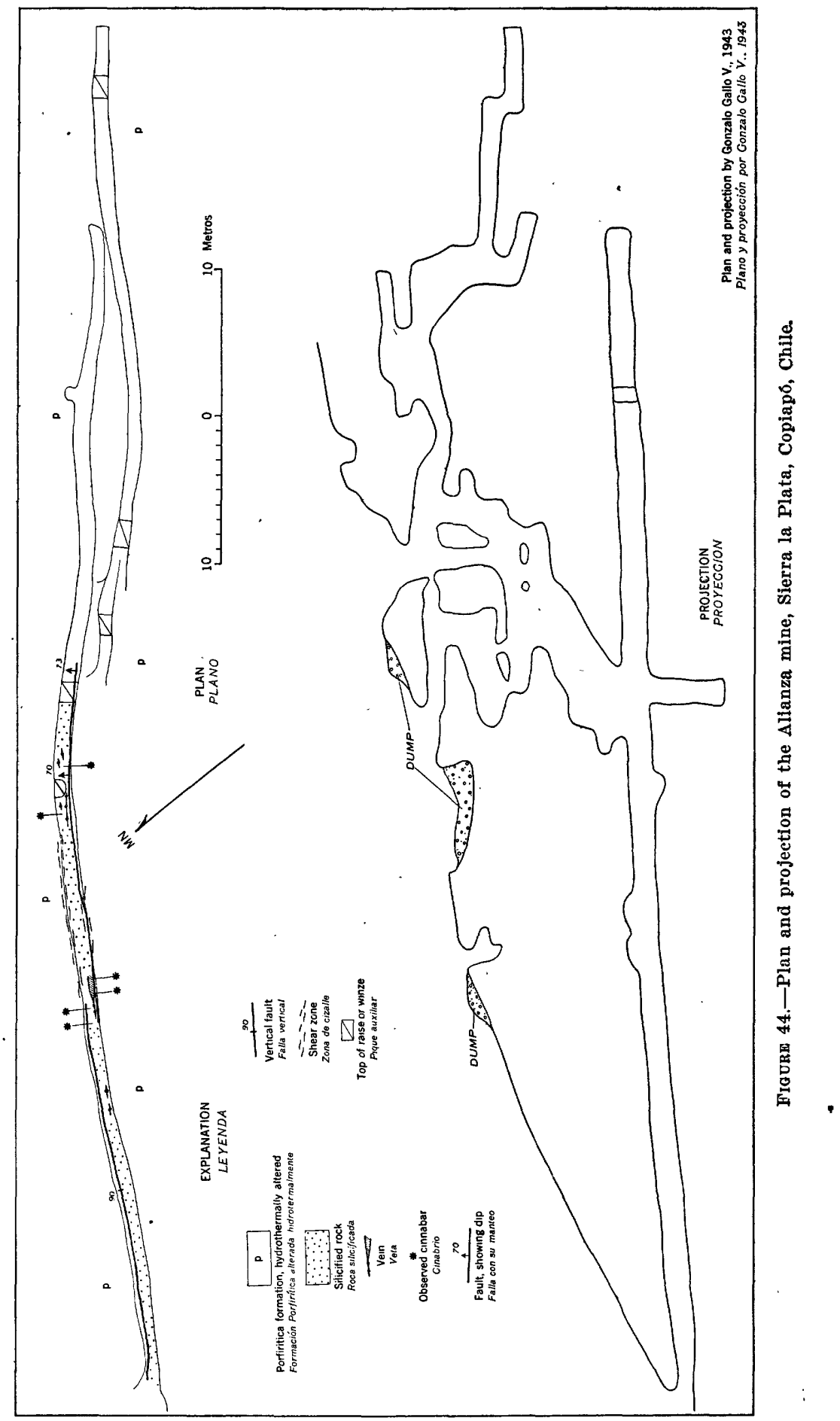


upon a more general alteration, which resulted in the formation of chlorite and epidote and in some alkalinization of the plagioclase.

Fragments of granitic rocks on the ridges near the mine are not from nearby outcrops but are remnants of a high-terrace gravel. A welldeveloped terrace is conspicuous on the other side of Quebrada de Cerrillos.

The rocks in the mapped area (fig. 43) dip consistently $20^{\circ}$ to $30^{\circ}$ SE. The structure that controlled the mineralization is a narrow shear zone, well exposed in the long lower adit of the Alianza mine. Its fault surfaces strike about N. $60^{\circ} \mathrm{W}$. (magnetic) ; they are essentially vertical or dip steeply northeast, and are rather discontinuous within the zone (fig. 44). The rock in the fault zone is completely altered, largely to clay minerals, and the alteration extends across the area farther than the clear-cut faults and the mineralized area; it continues northwest for 150 meters from the lower adit to the edge of the map, and southeast for 350 meters. In line with this zone of alteration, about 180 meters southeast of its end, is a patch of silicified rock about 40 meters in diameter, and 320 meters farther southeast begins another narrow zone of alteration, which continues for 250 meters, to the southeast corner of the mapped area. Near the center of the area shown on the map (fig. 43), or 350 meters southeast of the Alianza adit, a thin vein of barite striking N. $55^{\circ} \mathrm{W}$. branches from the zone of alteration exposed at the mine and extends northwestward for about 50 meters. This vein seemed to be barren.

The vein minerals at the Alianza mine consist of a powdery mixture of cinnabar with oxides and copper minerals of oxidation, in a barite gangue. The principal ore shoot, to judge from the outline of the mine workings (fig. 44), was somewhat irregular but in general plunged about $55^{\circ} \mathrm{NW}$. over a length of 25 meters. There was another shoot, which apparently plunged somewhat to the southeast, but because of the irregularity of the workings along it, and their inaccessibility, its form and attitude are uncertain. 

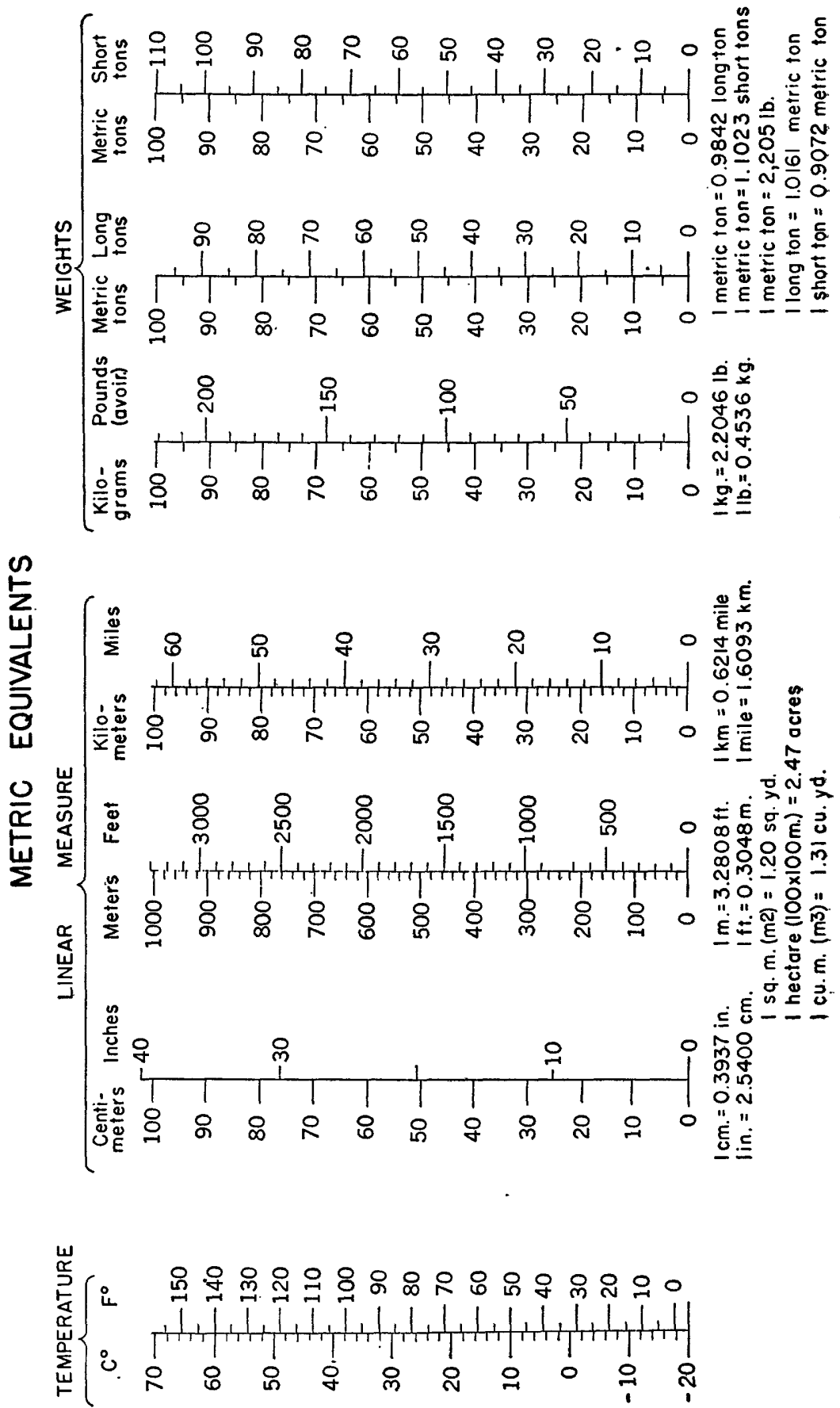


\section{INDEX}

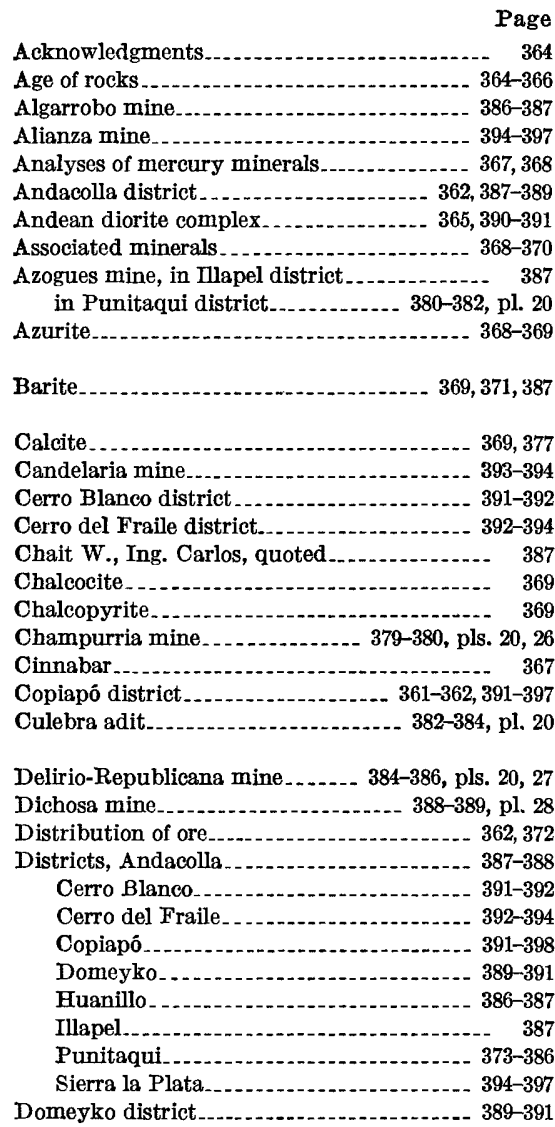

Faults, relation to distribution of rocks.

Illapel district....... 362, 387-389 Inclusion granite. See Andean diorite complex.

Lamprophyre dikes . .................. 366, 374, 381

Limonite..................... 369

Little, J. M., quoted . .

Location of deposits . . . . .

Los Mantos mine, description of ............. 378-379 maps of _....._._._._._. pls. 21, 22, 23, 24, 25 Luisiana mine.................................. 389-391

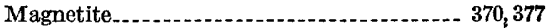

Malachite....................... 368-369

Manganese oxides....................... 370

Maps, geologic . . . . . . . ............. 381, 383, 390, 395,

pls. $20,21,22,23,24,25,26,27,28,29,30$

index map............................ 362

plan and projection of Alianza mine. ..... 396

sources of

Merceditas mine....................... 389, pl. 29

Mercurian tetrahedrite.

Metric equivalents, table................. 398

Minerals, associated with mercury ........ $368-370$

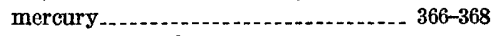

See also individual mines.

Mines, Algarrobo_.................... 386-387

Alianza.............. 394-397

Azogues mine, Illapel district ............... 387 Punitaqui district._._._._. 380-382, pl. 20

Candelaria.. . .

Champurria.......... 379-380. pls. 20,26

Culebra adit...................... 382-384, pl. 20

Delirio-Republicana.......... 384-386, pls. 20, 27

Dichosa......................... 388-389, pl. 28

Los Mantos_........ 378-379, pls. 21, 22, 23, 24, 25

Luisiana..................................... 388-391

Merceditas

Mirador property _................ 391-392, pl. 30

Negra ............. 392-393

Regalona prospect_..-_................ 394

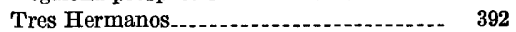

Fault zones, in Punitaqui district........- 374-376, pls. $20,21,22,23,24,25,26,27$.

See also under description of individual mines.

Field work . ......... 363-364

Florida mine. See Los Mantos mine.

Gold . . . . . . . .

Grade of ore

Hematite

History, of the mineral deposits ... . . . . . $370-372$ of mercury mining

Huanillo District......................... 362, 386-387

Mirador property

Molle mine. See Los Mantos mine.

Native mercury

Negra mine. . .

Ore deposits...

Porfiritica formation............... 364-365, 373-377

See also under individual mines.

Punitaqui district, Azogues mine -.- 380-382, pl. 20

Delirio-Republicana mine. . . 384-386, pls. 20, 27

Champurria mine. ........... 379-380, pls. 20,26

Culebra adit_................... 382-384, pl. 20 
Punitaqui district-Continued

location

Los Mantos mine.... 378-379, pl. 21, 22, 23, 24, 25 minerals. (378-

See also under Minerals. structural features i 371-377, rocks of

\section{Quartz.}

Regalona prospect.......

Reserves of ore.

Rocks, distribution and age of .............. 364-366 of Punitaqui district...................... 373-374 volcanic................... 364-365, 389, 395-397

Sierra la Plata district....................... 394-397

Size and grade of ore deposits............. 372-373 


\section{Geologic}

Investigations in the American Republics 1949

GE O L O G I A A S U R V E Y B U L L E T I N 964

This bulletin was printed as separate chapters, $A-E$, inclusive

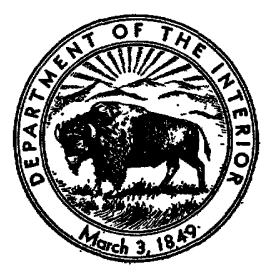




\section{UNITED STATES DEPARTMENT OF THE INTERIOR}

Oscar L. Chapman, Secretary

\section{GEOLOGICAL SURVEY}

W. E. Wrather, Director 


\section{CONTENTS}

[The letters in parentheses preceding the titles are those used to designate the papers for separate publication]

(A) Manganese deposits of the Serra do Navio district, Territory of Amapá, Brazil, by John Van N. Dorr 2d, Charles F. Park, Jr., and Glycon de Paiva

(B) Mineral resources of Colombia (other than petroleum), by Quentin D. Singewald .

(C) Mica deposits in Minas Gerais, Brazil, by W. T. Pecora, M. R. Klepper, and D. M. Larrabee, A. L. M. Barbosa and Resk Frayha

(D) Geology and mineral resources of the Maimon-Hatillo district, Dominican Republic, by A. H. Koschmann and Mackenzie Gordon, Jr -

(E) Quicksilver deposits of Chile, by J. F. McAllister, Hector Flores, W., and Carlos Ruiz F. . . .

\section{ILLUSTRATIONS}

Plate 1. Map of the Amapari-Araguari river systems, Federal Territory of Amapá, Brazil _. . . . . . .

2. Map showing relative positions of manganese deposits, Serra do

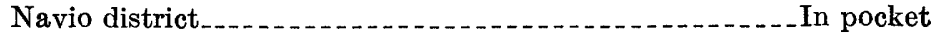

3. Map of the Clemente I, Navio, De Paiva, and Fritz Ackermann

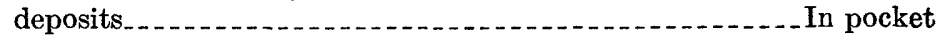

4. Map of part of the Chumbo area, showing manganese deposits... . . . . . . . . .

5. Index map of part of Colombia, South America . . .......... In pocket

6. Map showing principal deposits of antimony, asbestos, iron, manganese, mercury, and sulphur, Colombia_............. In pocket

7. Map showing principal sources of barite, cement, gypsum, and salt, Colombia . .

8. Map showing coal fields, Colombia . . . . . .

9. Map showing copper, lead, molybdenum, and zinc prospects, Colombia_._.

10. Map showing principal sources of emeralds and gold, Colombia . . . . .

11. Plan and sections of the lower adits, Quindío mine, municipio of Cajamarca, Tolima, Colombia .

12. Map showing principal mica, optical calcite, and quartz crystal mines and prospects, Colombia

13. Map and sections of the Alumbral quartz crystal mine, municipio of Muzo, Boyacá, Colombia....... In pocket

14. Schematic diagrams showing spatial distribution of principal minerals in symmetrically zoned pegmatites of Minas Gerais, Brazil. In pocket 
Prate 15. Cruzeiro mica mine (Minas Gerais), No. 1 pegmatite, Toquinho workings. In pocket

16. Structure sections showing asymmetrical zone in the Borges pegmatite and segregation patches in the Levindo Alfreres pegmatite, Minas Gerais . . . . . . . . . . . pocket

17. Sketches showing zones and mica shoots in selected pegmatites, Minas Gerais . . . . . . In pocket

18. Index map of the Dominican Republic ................ In pocket

19. Geologic map and sections of the Maimon-Hatillo district, Dominican Republic........ In pocket

20. Geologic and topographic map of the Punitaqui quicksilver district, Coquimbo, Chile_....... In pocket

21. Geologic map of the 170 level, Los Mantos mine, Punitaqui, Chile. ............ In pocket

22. Geologic map of the 250 level, Los Mantos mine, Punitaqui, Chile . . . . In pocket

23. Geologic sections, Los Mantos mine, Punitaqui, Chile _.... In pocket

24. Geologic map of the 330 adit, Los Mantos mine, Punitaqui, Chile .............. In pocket

25. Geologic maps of exploration adits, Los Mantos mine, Punitaqui, Chile............ In pocket

26. Geologic map of the 370 level, Champurria mine, Punitaqui, Chile. . . . . . . . In pocket

27. Geologic maps and sections of the Delerio-Republicana mine, Punitaqui, Chile. . . . . . . In pocket

28. Geologic sketch of the Dichosa quicksilver mine, Andacolla, Chile. . . . . . . . . In pocket

29. Geologic and topographic sketch map, Merceditas quicksilver deposit, Andacolla, Chile........... In pocket

30. Geologic map of the Mirador quicksilver deposit, Cerro Blanco, Copiapó, Chile........... In pocket

Frgure 1. Index map showing the location of the Serra do Navio district_ 2

2. Sketch of the Quindío mercury mine area, municipio of Cajamarca, Tolima, Colombia _.......... 152

3. Sketch map of part of the Intendencia del Choco, Colombia_- 169

4. Sketch map and section of the Santa Maria quartz crystal prospect, municipio of Maceo, Antioquia, Colombia........

5. Sketch of Cuincha quartz crystal prospect, municipio of Muzo, Boyacá, Colombia

6. Sheet-mica exports from Brazil, 1900-1945, and strategicmica exports, $1940-45$

7. Map showing princjpal mica-producing areas in eastern Minas Gerais

8. Serra do Capara6, Minas Gerais, viewed from hills on west.--

9. Planalto Brasileiro, looking north from Serra dos Lourenços_.

10. General view of topography near Fazenda Chico Dentista, Espera Feliz

11. "Gulley gravure," or rapid-erosion gulleys, near Governador Veladares.

12. Fault scarp on south side of Serra dos Lourenços . . . . . .

13. Poainha escarpment, viewed from west . .

14. Bedding in quartzite formation of Poainha escarpment at Morro do Cruzeiro. 
Figure 15. Scalloped abrasion in phyllitic rocks at Cachoeira Grande, Rio Suassuí Grande.

16. Projection and sketch showing relations of pegmatite, aplite, and schist at Serra dos Lourenços mica mine .............

17. Plan of main level, Forattini mica mine, Cruzeiro district....

18. Structure sections showing size, form, and attitude of 11 tabular and lenticular pegmatites, Minas Gerais

19. Structure sections showing size, form, and attitude of three single-sheet and two multiple-sheet pegmatites, Minas Gerais.

20. Structure sections showing size, form, and attitude of eight irregularly formed pegmatites, Minas Gerais . . . . . .....

21. Irregular contact of pegmatite and schist at lower Urubú mine, neas Espera Feliz

22. Irregular contact of pegmatite and schist at Carajáu mine, near Governador Valadares.

23. Pegmatite enclosed in minor drag fold of schist in roof of Carajáu pegmatite.

24. Transverse structure sections, No. 1 pegmatite, Serra dos Lourenços mica mine.

25. Sketches along drifts and stopes of Bananal mica mine.....-

26. Granjtic texture in upper border zone of Ipê pegmatite, near

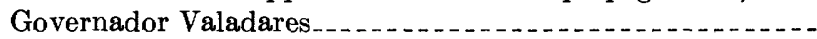

27. Pegmatite texture in central zone of Ipê pegmatite

28. Zoning in Pedra Redonda No. 1 pegmatite, near Governador Valadares

29. Structure sections of Zacarias, Pequerí, Saracura, and Fazendinha pegmatites

30. Plan and structure section of Sapucaia pegmatite

31. Sketches transverse to stopes in Cruzeiro No. 2 and No. 3

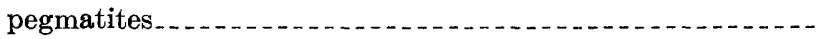

32. Transverse sections of the Pedro Espirito, Golconda, and Ipê pegmatites . . . . . . .

33. Sketches of pegmatites exposed at Pedra Redonda No. 1 and

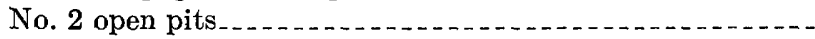

34. Exceptionally large full-trimmed sheet mica from Manoel Blum mine, near Tombos. . . . . . . . . . . . . . .

35. Rifted mica split from single large book from Cruzeiro No. 1 pegmatite, near Santa Maria do Suassui .................

36. Sketch of a mica plate, showing relation of principal structural imperfections to crystallographic orientation ..............

37. Pedro Espirito mica mine, near Governador Valadares, showing open pit in March 1944

38. Pedro Espirito mica mine, showing working of benches by

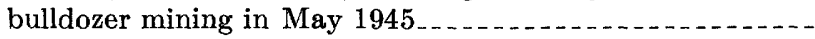

39. Index map of Chile, showing quicksilver region . . .

40. Geologic map of the main level, Azogues mine, Punitaqui, Chile

41. Geologic map of the Culebra adit, Punitaqui, Chile .........

42. Geologic map and section of the Luisiana quicksilver mine,

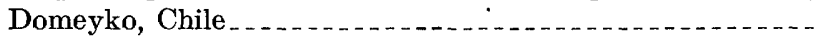

43. Geologic map of the Alianza quicksilver deposit Sierra la

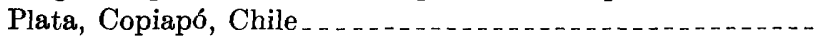

44. Plan and projection of the Alianza mine, Sierra la Plata,

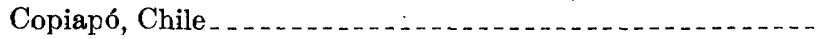




